\title{
The Impact of Environmental Regulation on Firm and Country Competitiveness: A Meta-Analysis of the Porter Hypothesis*
}

\author{
Mark A. Cohen \\ Vanderbilt University \\ and \\ Resources for the Future \\ Adeline Tubb \\ University College London
}

August 2017

* This research was funded through a grant from the Centre for International Governance Innovation and Institute for New Economic Thinking (CIGI-INET Partnership). Mark Cohen also acknowledges research funding from the Owen Graduate School of Management. The authors would like to thank Stewart Elgie, Nick Johnstone, Jon Nelson, David Wilson, David Popp, Anthony Heyes, and Paul Lanoie for their valuable suggestions in the development of this project, and three anonymous referees for helpful comments on earlier drafts. In addition, we gratefully acknowledge the research assistance provided by Yunting Ge, Hanchen Jiang, Sushil Khadha, Loren Lipsey, Jizhou Liu, Jiali Pan, Rajan Walia and Ying Zheng.

JEL Codes: Q52, Q58, H23, L21, F14

Keywords: Porter Hypothesis, environmental policy, competitiveness, financial performance 
The Impact of Environmental Regulation on Competitiveness:

A Meta-Analysis of the Porter Hypothesis

\begin{abstract}
Since the early 1990s, the validity of the Porter Hypothesis has been the focus of intense research to establish whether well-designed environmental regulation may enhance - rather than reduce - competitiveness. However, little consensus exists on the extent to which environmental regulation might generate profitability enhancing innovation offsets. This paper reports on a meta-analysis of 103 publications which estimate the relationship between environmental regulation and firm or country-level productivity or competitiveness. We find considerable heterogeneity in both the sign and significance level of over 2,000 estimated "effect sizes" in these studies. A positive effect of environmental regulation is more likely at the state, region or country level, compared to facility, firm or industry level although in both cases the most likely scenario is statistical insignificance. These findings are consistent with the strong version of the Porter Hypothesis whereby strict but flexible environmental regulations induce innovation and over time increase country-level competitiveness.
\end{abstract}




\section{The Impact of Environmental Regulation on Competitiveness: A Meta-Analysis of the Porter Hypothesis}

\section{Introduction}

Conventional economic wisdom has long held that environmental protection is costly to firms required to comply with government regulations. By definition, adding a constraint to the production possibility set such as requiring less pollution from a firm that is otherwise profit maximizing can only reduce profitability (Palmer, Oates and Portney, 1995). Yet, a revisionist view emerged in the early 1990s, crystalized by Porter (1991) and Porter and van der Linde (1995) who posited that regulation could potentially enhance productivity and/or competitiveness by generating substantial "innovation offsets". What has since become known as the Porter Hypothesis suggests that environmental regulation may provide an incentive for firms to innovate, which can improve productivity and in some cases even result in lower costs. As Jaffe and Palmer (1997) noted, there are several forms that the Porter Hypothesis might take:

- The 'weak'version: environmental regulations will stimulate 'certain kinds' of innovation, for which the opportunity cost exceeds the direct benefits to the firm.

- The 'strong' version: these regulation-driven "innovation offsets'" can often exceed the costs of regulatory compliance, resulting in net productivity gains.

- The 'narrow' version: well-designed (i.e. flexible, market-based) regulations give firms greater incentives to innovate and will have less adverse impact on productivity than prescriptive regulations. 
Numerous studies have tested each of these hypotheses, often reaching different conclusions (Lankoski, 2010). For example, while most studies find that environmental regulation generally spurs innovation, there is significant disagreement over the strength of this signal and the nature of the resulting innovation (Johnstone et al., 2009; Hascic and Johnstone, 2011). The greatest conflict surrounds how environmental regulation affects competitiveness (normally measured through productivity). Most early studies concluded that it negatively affected productivity - often significantly (Palmer et al., 1995). The second decade of research has produced more mixed results. Several studies, for example, find that under certain circumstances, environmental regulation can have a positive effect on productivity (Berman and Bui, 2001; Lanoie et al., 2008).

The strong version of the Porter Hypothesis has been particularly controversial. This is unsurprising given that the notion that firms will ignore opportunities to improve financial performance until encouraged to do so by the imposition of government regulations directly contradicts the profit maximization assumption of neoclassical economics. Ambec et al. (2013) review a cross-section of these studies and posit a range of factors that may explain the conflicting results. These include: the variability of the regulatory approach; the firm's sector and market conditions; the environmental problem being addressed; the firm's governance and management approach; and the research methodology. They also note that more recent studies of the strong version of the Porter Hypothesis tend to find positive results compared to earlier negative findings. 
Given the significant and broad reaching environmental, economic, and distributional impacts of environmental policy, it is important firstly to understand why the literature on the Porter Hypothesis reaches such divergent conclusions, and secondly why the balance of positive and negative findings on the relationship between environmental regulation and competitiveness appears to be shifting over time. To what extent is it due to methodological differences (e.g. how productivity or innovation is measured) or publication bias (i.e. researchers may work harder to 'prove' the Porter Hypothesis as time goes on)? To what extent does it stem from differences in regulatory approaches (e.g. flexible or market-based instruments), characteristics of the firm (e.g. the industry, or degree of competitiveness), or other factors (e.g. available technological substitutes)? Without a systematic empirical comparison of findings in the literature, it is difficult to assess the importance of these factors and ultimately to judge if and when the Porter Hypothesis is valid. ${ }^{1}$ In response to the lack of clarity surrounding the validity of the Porter Hypothesis and the significant public policy implications following from a comprehensive understanding of the conditions under which the hypothesis does and does not hold, this paper reports on the results of a systematic meta-analysis of 103 publications that empirically estimate the relationship between environmental regulation and measures of firm or country-level productivity or competitiveness. ${ }^{2}$ The next section briefly describes the meta-analysis methodology and how it applies

${ }^{1}$ Indeed, one of the recommendations of Ambec et al. (2013) is a call for a metaanalysis of previous research.

${ }^{2}$ Since the focus of this meta-analysis is the relationship between environmental regulation and firm or country-level productivity or competitiveness, we are directly considering only the 'strong' version of the Porter Hypothesis. 
to our study. Section III summarizes our search methodology and how we determine the sample of eligible empirical publications examining the relationship between environmental regulation and competitiveness, while section IV describes the variables coded. Section V summarizes our data set and provides an initial look at the wide variance in study designs. Our findings are reported in section VI. Concluding remarks and directions for future research are contained in Section VII.

\section{Meta-Analysis}

Meta-analysis is an empirical methodology that endeavors to aggregate the findings of different studies investigating the same underlying relationship. In our case, the underlying relationship is the impact of environmental regulation on productivity and competitiveness. Analyses have reached different conclusions using different data, research methodologies, measures of environmental regulation and measures of productivity or competitiveness - but they all seek to explain the same phenomenon.

In a meta-analysis, each study is treated as an individual observation. It is a well-accepted methodology that has generated a significant literature and best practice approaches in many disciplines including environmental economics. Nelson and Kennedy (2009: 346) report on an analysis of 140 meta-analyses in environmental economics, and explain:

Briefly, the investigator collects a set of primary studies that contain a common empirical outcome, such as the long-run price elasticity of gasoline, the willingness-to-pay (WTP) for freshwater quality, or the influence of air pollution on property values. In contrast to controlled experiments in the natural sciences, the primary studies in economics employ different study designs, model specifications, and econometric techniques. In a metaregression, the dependent variable is a common summary statistic or "effectsize," such as a regression coefficient for the price elasticity, a predicted value 
for the WTP, or significance level of the air pollution coefficient. One or more values of this statistic are drawn from each primary study. It is of crucial importance that this dependent variable is measuring the same economic concept across primary studies. The moderator (independent) variables in the regression include characteristics of the primary data, study design, valuation method, sample size, model specification, econometric methods, and other "quality" variables such as place and date of publication.

There are several possible goals of a meta-analysis. In some cases, the analyst is interested in estimating a weighted average mean "effect size" which might be an elasticity or monetary value. In some cases, however, the only question is whether or not the sign of the underlying relationship is positive or negative (and/or statistically significant). In other cases, the goal is not to estimate one average effect, but instead, to attempt to explain the heterogeneity that is observed across studies.

A recent meta-analysis by Horváthová (2010) illustrates how this method can be useful in explaining conflicting studies. Horváthová analyzes the findings of 37 publications that test the linkage between environmental performance and financial performance. For example, she finds that the empirical method used matters - with simple correlations tending to result in negative findings while more sophisticated econometric models find a positive relationship. She also finds differences across countries and time.

\section{Search Methodology}

Typically, search procedures for meta-analyses focus on title, abstract and keywords in only one or a small number of primary databases. However, in many areas of empirical economics this approach is likely to be insufficient. Our search protocol is much more extensive in order to guarantee - to the greatest degree possible - that all relevant papers are identified (Nelson 2013). 
We first conducted an extensive review of the literature, including the following sources:

- All empirical papers cited within known literature reviews including Jaffe et al. (1995), Copeland and Taylor (2004), Brunnermeier and Levinson (2004), Lankoski (2009), Iraldo et al. (2011) and Ambec et al. (2013).

- Citation searches using Google Scholar of the above literature reviews and the relevant empirical studies cited therein.

- Keyword searches in Google Scholar, EconLit, SSRN, AgEcon, and ProQuest Dissertations, using the combinations of (environment/al regulation, environment/al policy, climate change policy) with competitiveness, financial performance, economic performance, Tobin's q, ROI, profitability, R\&D, innovation, patents, capital, productivity, and technology. Additional searches were conducted for the terms Porter Hypothesis and pollution haven hypothesis.

- Technical reports and working papers were searched from the following organizations: CESifo, US EPA, National Technical Information Service, Office of Technology Assessment, Congressional Budget Office, European Academy of Business in Society, Academy of Management's Organizations and the Natural Environment, Network for Business Sustainability, Resources for the Future, Swedish Foundation for Strategic Environmental Research, US Department of Agriculture (Economic Research Service), and national statistical agencies in Norway, Sweden, Netherlands and the UK. 
- Personal emails were sent to 26 key authors requesting any relevant unpublished papers or empirical results. We received replies from 20 of these authors supplementing our original search or confirming that they did not have any additional research to consider; searches of the researcher websites of the remaining six authors were conducted to uncover any additional papers.

This process resulted in 1,055 publications being identified for screening (see Table 1). From that initial set, 649 were empirical studies that appeared to be related to the Porter Hypothesis, and thus required more detailed review. From that set of 649, each publication was reviewed for eligibility to determine if there were empirical findings related to the Porter Hypothesis that could be coded. We identified 14 ineligible "review articles," and 27 publications that focused on voluntary initiatives instead of mandatory government regulation. Of the remaining empirical studies that focused on mandatory regulation, 103 were eligible for final coding. To be eligible, the publication must include an empirical estimate of the impact of mandatory environmental regulation on (a) facility, firm, or industry performance, and/or (b) state, regional, or country-level competitiveness. In many cases, an earlier unpublished working paper was found along with a published version of the same paper. In those instances, each table of the working paper was compared to the published version. In 11 publications, one or more regression results in a working paper differed from the published version, and they were 
treated as additional tables to the published version (and identified separately as being from a working paper). ${ }^{3}$

Our meta-analysis therefore focuses on the 103 publications (in addition to related working papers) listed in Appendix A, and 2,025 effect sizes (usually regression coefficients) that address firm or facility-level productivity or profitability or state, regional, or country-level competitiveness. Four publications (two of which were dissertations) analyzed more than one dataset independently and were treated as two separate publications in our analysis. Thus, while we empirically analyzed 103 distinct publications and their associated working papers, we consider our sample to be 107 studies. Each of the publication sources is listed in Appendix B.

The diversity of publication sources is striking. Of the 103 unique publications coded, 16 were unpublished working papers, 4 were dissertations and 2 were book chapters which are not associated with publication in an academic journal. Thus, we coded a total of 81 unique academic publications from 53 different journals. The most frequent journal was Ecological Economics (10 publications),

${ }^{3}$ As normally dictated by best practice in the meta-analysis field (Stanley and Doucouliagos 2012), these additional model specifications and effect sizes were coded and included along with the effect sizes reported in the published paper. Results from a working paper differed from a published version in only 11 publications - and generally the results are only slightly different. (7 of the 11 working papers came from the recent time period, 2011-2015. The working papers come from a diverse set of institutions around the world, including smaller universities and research institutes.) Moreover, as discussed later in the paper, each effect size is weighted by the reciprocal of the number of effect sizes in a particular study; hence, inclusion of additional effect sizes from a working paper does not increase the weight given to that publication. In addition, some of our analysis is limited to the "preferred specification" from a publication - which would always exclude findings from a working paper when a published paper was available. 
followed by Environmental and Resource Economics (5), Journal of Productivity Analysis and Journal of Public Economics (3 each). An additional 11 journals each had 2 publications (Economics Letters, Energy Policy, Journal of Environmental Management, Journal of Political Economy, Kyklos, Land Economics, Public Administration Review, Research Policy, Resources and Energy Economics, Review of Economics and Statistics, and The World Economy), while 39 journals had only one published article in our sample. Fields ranged widely from leading general interest economics journals to more specialized discipline and field journals in environmental economics, management, industrial ecology, public policy, development, and others.

There were 177 distinct authors among these 103 publications. Only 23 authors had more than one paper in our sample. The top authors with four papers each were Dietrich Earnhart and Dylan Rassier (each co-authoring the same four papers), Wayne Gray, and Shunsuke Managi. Valeria Costantini, Paul Lanoie and Ronald Shadbegian each had three publications. Appendix C contains a complete list of authors with more than one paper, their affiliation at the time of publication, and all of their coauthors.

The number of effect sizes reported in each publication ranged from as little as one to as many as $121 .^{4}$ The median number of effect sizes per publication was 10. As shown in Table 2, of the 107 studies we analyze in this paper, 70 focus on facility, firm or industry-level productivity or profitability ( 45 of which are at the

${ }^{4}$ As discussed in Section $V$, we have dealt with the lack of statistical independence of multiple effect sizes within each study in two alternative ways. First, we weight each effect size by the reciprocal of the number of effect sizes in that particular study. Second, we choose a "preferred" effect size for each study. 
firm or facility level and 25 at the industry level), while 37 focus on state, regional or country-level competitiveness. We exclude papers that focus primarily on the "pollution haven hypothesis" where the dependent variable is either foreign direct investment (FDI) or the geographic location of plant births and/or closures. ${ }^{5}$ Instead, the 37 studies on state, regional or country-level competitiveness examine outcomes such as international trade flows, output measures, and productivity.

Following Lipsey and Wilson (2001), the coding protocol consists of two components - a coding form and a coding manual. ${ }^{6}$ The coding manual contains comprehensive instructions directing the coder how to consistently code each variable of interest onto the coding form. We developed the coding manual guided by two strands of the academic literature. First, we followed best practice in the meta-analysis literature by including standard fields for publication and effect size information (e.g., publication name, year of publication, authors, data years, sample size and unit of observation). Second, we paid close attention to the Porter Hypothesis literature to determine which environmental regulation and effect size variables were likely to be important in explaining the wide divergence of published outcomes (e.g. environmental regulation type and measure, data source, target of environmental regulation). Following development of the draft coding protocol, a one-day 'expert panel' was convened to discuss improvements and refinements. The

\footnotetext{
${ }^{5}$ Note that several papers in this study primarily focus on the pollution-haven hypothesis but also include outcome measures such as net employment or GDP (see, e.g., Fredriksson et al., 2003 in Appendix A). In those instances, we include the empirical results obtained using competitiveness outcome measures (net employment or GDP) from these studies; but exclude the effect sizes focusing on FDI or geographic plant births/closures.

${ }^{6}$ Available on request.
} 
expert panel consisted of leading researchers in the fields of meta-analysis and/or environmental economics. ${ }^{7}$ Following this meeting, the coding protocol was finalized based on feedback from the expert panel.

Following comprehensive coder training sessions, each publication was initially coded by a research assistant based at either Vanderbilt University or the University of Ottawa. Each coder was a current or former graduate student selected on the basis of his/her knowledge of environmental economics and econometrics. Following initial coding, the coding database was systematically checked by one of the lead researchers for consistency and coding errors.

Document searches took place beginning in the Fall of 2012, with updates through June 2014. Thus, the above search process should be considered complete as of the end of June 2014. However, during the collection of external data and in preparing the dataset during the summer of 2015, we conducted a systematic review of each paper to determine whether or not there were more recent versions available - either a revised working paper or a published version of a dissertation or working paper in our dataset. If a publication that was identified by our search process ending June 2014 had been updated or published as of the end of July 2015, the more recent version was included. Thus, while some of the papers are dated past mid-2014, according to the search criteria any new published or unpublished papers that first appeared after mid-2014 are excluded.

\footnotetext{
7 The expert panel members were Stewart Elgie, Anthony Heyes, Nick Johnstone, Paul Lanoie, Jon Nelson, David Popp, and David Wilson. They share no blame for any errors in design or execution - only thanks for their assistance and devoting their valuable time to this project.
} 


\section{Variables Coded}

A total of 20 variables were coded at the "publication level", including date, author(s), funding source(s), publication outlet, range of years for the dataset, sample size, unit of observation (e.g. facility, firm, industry, country), industrial sector(s), country(ies) in which the data are based, purpose of the study, whether Porter was mentioned in the text or abstract, and any sample restrictions placed on the data.

A total of 11 variables were coded for each dependent variable, including the variable measure (e.g. output, accounting profit, stock prices, or self-reported performance in the case of firms, or GDP, growth rates, employment, etc. in the case of countries), its format (level, log, binary, categorical, index), mean, and standard deviation. In addition, source and sampling details were coded, such as whether it was quantitative or qualitative official agency data, researcher, trade association or other survey data. In the case of survey data, information about the sampling strategy and response rate was also coded. Identical variables were collected for each environmental regulation being studied - although here the variable measures are replaced with the relevant descriptors such as pollution abatement and control expenditures, number of inspections, number of regulations, non-compliance fees, regulatory stringency, etc. In addition, each regulation variable was identified as being a technology standard, emission standard, emission tax, cap and trade, regulatory disclosure, etc. Finally, the regulatory target (air, GHG emissions, water, etc.) was identified. 
Finally, 30 additional variables were coded for each effect size. When available, we coded the sign of the unstandardized regression coefficient and its size and standard error, t-statistic, p-value, the direction of the relationship between the environmental regulation variable and competitiveness, level of significance $(1 \%$, $5 \%, 10 \%$, insignificant), number of observations, data structure (cross-section, time series, etc.), whether this was a subsample of the full study data, the econometric model (OLS, 2SLS, GLS, Tobit, etc.), whether there was any lag structure in the model, instrumental variables, and detailed information about the number and type of independent variables included in the model.

\section{Data Description}

This section briefly summarizes the data that was coded for our 107 studies.

\section{Publication/Sample Characteristics}

Table 3 summarizes the publication-level data. Some of these studies are based on data that are quite old - with two studies including data from 1958 and 16 studies including data from prior to 1976. About half of the publications include data from 1990 or earlier. Only 36 studies (34\%) contain data with an earliest date of 1996 or later, with one paper whose earliest data was from 2009 and one from 2010. The median 'start date' was 1999. Not shown, the earliest 'end date' (the date at which a study's data ended) was 1975 with the latest being 2010 and the median 1999. Thus, there is a wide range of data and many studies with data ending in the early to mid-1990s.

The date of publication ranges from 1982 through 2015 with the median publication date being 2008. Only four studies were published prior to 1991, the 
year in which Porter first published his claim that regulation might have a positive impact on competitiveness. ${ }^{8}$ About two-thirds of the studies (69/107) mention the Porter Hypothesis or cite one of Michael Porter's relevant papers in their references. Facility, firm or industry-level studies were more likely to mention Porter (68\% 48/70) than state, regional or country-level studies (57\% - 21/37).

Overall, about 34\% (37 out of 107) of the studies in our sample are based solely on U.S. data, while 16\% (17 out of 107) are based on countries in the OECD and another $23 \%$ from EU only countries. Only 12 studies are global and include countries that span these other categories. Aside from the 37 US-based studies, there were 36 other studies published using data from only one country: four from India, three each from Japan, the Netherlands, and Sweden, two from Canada, China, Germany, Mexico, Spain, Switzerland, Taiwan, and the U.K., and one each from Austria, Brazil, France, Korea, New Zealand, and Norway. ${ }^{9}$

One of the common critiques of the existing literature is the fact that most studies are cross-sectional, thus making any causal inferences problematic (see, e.g., Lankoski, 2010; and Ambec et al., 2013), as the Porter Hypothesis anticipates a lag between the time that regulations are implemented, firms innovate, and competitive outcomes are realized (Porter and van der Linde, 1995: 108). Furthermore, as Brunel and Levinson (2016) emphasize, simultaneity presents a significant challenge in studies seeking to address the impact of environmental regulation on

${ }^{8}$ In all four studies, effect sizes were either negative or statistically insignificant; consistent with the prevailing view at the time that environmental regulation was detrimental to competitiveness.

${ }^{9}$ All but 11 of these single-country studies are included in the earlier categories. The remaining countries outside the EU, Europe, and the OECD include Brazil, China, India, Mexico and Taiwan. 
competitiveness, since competitiveness may simultaneously contribute to regulatory stringency. Researchers typically seek to address the simultaneity of environmental regulations via natural experiments and the use of instrumental variables. The inclusion of instrumental variables also serves to address the possible endogeneity of regulation severity; since more stringent environmental regulation is politically more acceptable and hence more likely to be enacted when firms are prosperous, the estimated effect of environmental regulation on firm/facility competitiveness and profitability may be biased upward. We found only about $25 \%$ of studies (27 out of 107) included a lagged independent variable measure for regulation and 13\% (14 out of 107) used instrumental variables. However, approximately $70 \%$ (73 out of 107) of studies had at least one specification based on a panel dataset.

Dependent Variable Measures

Among the 107 studies, over 250 different dependent variable (i.e., "outcome level") measures were coded (although some of these are the same measures on different samples that were coded separately in order to estimate elasticities). Of the 150 outcome level variables at the firm or industry level, about 100 used output or productivity as the measure, while 50 relied upon accounting or stock price measures including intangible asset values. While most of the regional, state, or country-level dependent variables were based on international trade flows, other measures included growth in GDP and employment levels.

Environmental Regulation Measures 
One of the tenets of the Porter Hypothesis is that innovation offsets - and hence positive productivity or competitiveness - are more likely to be realized under flexible environmental regulations such as emission fees or marketable permits. Unfortunately, most of the studies utilize a broad measure of environmental regulation that does not permit such a fine distinction and comparison. In the set of 107 studies, the type of regulation can only be identified with adequate specificity to identify "command and control" (technology standards) regulation in seven papers, while more "flexible" measures (emission standards, taxes, cap and trade approaches, subsidies, etc.) were identified in 32 publications. Emission taxes were identified in 13 publications and cap and trade programs in four papers.

While some of the regulation measures were directly focused on the number or type of regulations, others were proxies that might be correlated with regulation but are often far from ideal measures (Brunel and Levinson 2016). The two most prevalent measures were pollution control expenditures (whether measured by operating expenses, investments or taxes) and perceived measures of regulatory stringency (whether objective such as the number of regulations or subjective analyses of researchers or survey respondents) - each representing about $45 \%$ of all effect sizes. The remaining measures which were used in the literature as proxies for environmental regulation were pollution emissions (5\%), government environmental enforcement or compliance expenditures (3\%), and government environmental R\&D expenditures (2\%), though each of these measures are considered problematic (Brunel and Levinson 2016). 
In most cases, the regulatory target was either unspecified or across media (i.e. multiple targets). Individual targets included water quality (contained in 18 publications), air quality (15), greenhouse gas emissions (10), waste (6), and energy efficiency (3).

\section{Findings}

\section{A. Comparison of Effect Sizes}

We start with the basic question underlying the strong version of the Porter Hypothesis - does environmental regulation increase productivity or competitiveness? Table 5 reports on the direction of the relationship between environmental regulation and these outcomes. In this table, we do not require statistically significant findings - instead, we simply record whether the relationship is positive or negative. The "equal weighted" rows represent the fraction of effect sizes that are negative or positive within each study. Thus, each study is given a weight of one but the directional relationship may be expressed as a fraction within each study. For example, if there are four effect sizes estimated in a study and only one was positive, that study would be weighted $25 \%$ positive and $75 \%$ negative.

Using this approach, about $54 \%$ of publications measuring facility, firm or industry-level impacts find a negative relationship, while $43 \%$ of those measuring state, regional or country-level competitiveness find a negative relationship. The "preferred specification" rows use only one effect size per publication (based on coder judgment taking into account any claims made by the authors as well as 
goodness of fit, model specification, and sample size). ${ }^{10}$ As shown, about $54 \%$ of studies find a negative relationship between environmental regulation and productivity or profitability at the facility, firm or industry level, while $46 \%$ find a negative relationship at the regional, state or country level. When combined, positive and negative findings are about equal. However, once disaggregated, there appears to be a higher chance of finding a negative finding at the facility, firm or industry level, and a higher chance of a positive finding at the state, regional or country level.

Table 6 reports on a similar comparison taking into account the significance level of the estimated relationship. Thus, in the equal-weighted case, $27 \%$ of facility, firm or industry-level studies find a negative and statistically significant relationship, and $27 \%$ have a positive and significant finding. However, at the state, regional or country level, while $12 \%$ find a negative and statistically significant relationship, $28 \%$ of findings show a positive and statistically significant relationship. Using the preferred specification, at the facility, firm, or industry-level, there is more likely to be a negative and statistically significant relationship (32\% versus $28 \%$ ) while at the state, regional or country level, we are more likely to find a positive and statistically significant relationship (32\% versus $14 \%)$. In all cases, however, the largest category is "insignificant." Once again, we find more support for the Porter Hypothesis at the state, regional or country level than at the firm or industry level.

${ }^{10}$ Note that in some cases, more than one environmental regulation variable is included in a regression equation, or a paper only reports on multiple subsamples. In those cases, for example, if the preferred specification included one positive and one negative coefficient, each would be given a weight of $50 \%$. 
In addition to examining the sign of the effect sizes, we calculated elasticity in cases where adequate information existed in the studies. For example, if the dependent variable and regulation variable were both measured in natural logs in a regression, we can directly impute the coefficient as an elasticity. Similarly, if one of the variables are continuous and not in log form, we can compute an elasticity if we have the respective mean for that variable in the regression sample. Overall, we were able to estimate elasticities in less than half of the studies, 46 out of 107. As shown in Table 2, out of the 2,025 effect sizes, we were able to estimate an elasticity in about one-third (647) of the cases. These elasticity estimates allow us to place study findings on a similar footing and provide more information about the magnitude and economic significance of any findings. They also allow us to test the statistical significance of effect sizes.

As shown in the first row of Table 7, excluding about $4 \%$ of cases with outliers (elasticity estimates greater than 5 in absolute value), the average elasticity estimated in these 46 studies was +.15 (when all elasticities within a study are used), and +.11 when only preferred specifications are used. ${ }^{11}$ These estimates are calculated by weighting each effect size by the square root of the number of observations that were used in the model that estimated the particular effect size, in

\footnotetext{
${ }^{11}$ In some cases, there were multiple elasticities within the preferred model specification. This might occur because there was either more than one environmental regulation variable in a regression model, or there were two different samples being used in a paper and both were determined to be preferred specifications. In those cases, the "within publication" preferred specification elasticities were given equal weight.
} 
addition to weights based on the number of effect sizes within each study. ${ }^{12}$ The $95 \%$ confidence interval for the elasticity using all specifications is +0.08 to +0.22 . However, once the sample is restricted to preferred specifications, the confidence interval no longer remains positive, ranging from -0.11 to +0.32 .

Because the dependent variables are considerably different across studies, Table 7 also reports elasticities for different dependent variable specifications. The dependent variable measured competitiveness (e.g., GDP, trade flows, or employment) in 16 publications, profit (e.g., accounting or stock prices, value added) in 12 publications, and output measures of productivity in 18 publications. Notably, the elasticity estimates (both positive and negative) are considerably smaller and the $95 \%$ confidence interval is between -0.08 and +0.01 when the dependent variable is a measure of firm profit compared to when it is a measure of either competitiveness or productivity.

Forest plots provide a useful graphical summary of mean effect sizes and corresponding confidence intervals in meta-analyses. Effect sizes are typically shown with blocks corresponding to the proportional weight assigned to each study. Figure 1 shows a Forest plot of partial correlations and corresponding standard

12 While it would be preferable to calculate a weight for the effect sizes based on the standard error of each elasticity estimate (perhaps combined with the number of effect sizes within each publication), the standard error was only available for 12 publications (and only in 9 publications with preferred specifications). Instead, to maintain a sufficient sample size of studies, we use the model's sample size to weight each elasticity. See Stanley and Doucouliagos (2012: 46). Further, because the sample sizes for elasticities found in these 46 studies ranged from 47 to 151,908, we used the square root of sample size for weighting purposes, since otherwise a few studies would entirely dominate the estimates. Alternative specifications of weights do not significantly alter the basic finding that using the preferred specification, the estimated elasticity is close to zero and statistically insignificant. 
errors for the set of preferred specifications in each study. ${ }^{13}$ We were able to estimate 1303 partial correlations in 73 studies (189 partial correlations and 70 studies using only the preferred specifications). The partial correlation of the preferred specification is displayed together with its confidence interval represented by a horizontal line. The area of the square represents the weight that the study contributes to the meta-analysis. Interestingly, the studies that contribute the most weight to the meta-analysis are clustered around an effect size of zero. Furthermore, taking into account the standard errors that cross zero, a slight majority of estimated effect sizes are zero. Overall, about $52 \%$ of estimated effect sizes are positive. Restricting the analysis to preferred specifications, $50 \%$ of the effect sizes are positive. The unweighted mean effect size is +0.013 (range -.53 to +.55 ), and +0.021 (range -.53 to +.51 ) using the preferred specifications. Weighting each effect size by its standard error (and number of effect sizes within each study), we can calculate a 95\% confidence interval around these estimates. For the full sample, the estimated mean effect size is +0.007 with a confidence interval of $[+0.003,+0.011]$. Using only preferred specifications, the mean effect size is +0.0025 with a confidence interval of $[-0.009,+0.015]$. Thus, we cannot reject the hypothesis that the underlying effect size is zero. ${ }^{14}$

${ }^{13}$ Unlike in the case of elasticities, we are able to use the preferred weights (standard errors), which are available in a large proportion of cases where we also are able to estimate partial correlations.

${ }^{14}$ However, as noted above, samples sizes varied considerably across studies; a fact that might substantially reduce standard errors and thus increase the weight given to any particular study. As a robustness check, we weighted each effect size by the square root of its corresponding sample size. However, this does not change our finding that we cannot reject the hypothesis of a zero average effect size. 
Publication bias - the preference for statistically significant results - is a pervasive issue in the social sciences (Stanley 2005; Stanley 2013). Indeed, given the potential for research surrounding the impact of environmental policy on competitiveness to significantly impact public policy discourse, it is important to examine the presence (or absence) of publication bias in studies empirically investigating the Porter Hypothesis. Figure 2 (full sample) and Figure 3 (preferred specifications only) consider the presence of potential publication bias via a "funnel plot" for all computable partial correlations and corresponding standard errors. Funnel plots graphically indicate possible publication bias by plotting an estimated effect on the horizontal axis along with its precision on the vertical axis. We would expect studies with the largest sample size to be plotted near average, since these studies are assumed to be more reliable and therefore less dispersed, and smaller studies spread evenly on both sides, therefore creating a distribution which approximates a funnel shape. ${ }^{15}$ Following Sterne and Egger (2001), we use the standard error of the computable partial correlations as the measure of study size. Given that in the absence of heterogeneity or selection bias, 95 percent of the studies should lie within the funnel defined by the pseudo 95\% confidence limits, these funnel plots indicate the potential presence of publication bias (Sterne and Harbord 2004). Using the statistical test suggested by Egger (1997), we reject symmetry in the full sample $(\mathrm{p}<.01)$, but cannot reject symmetry in the sample based on preferred specifications ( $\mathrm{p}=.20)$. Figures 2 and 3 provide some additional insights into the nature of the published studies on the Porter Hypothesis. First,

${ }^{15}$ See also Lipsey and Wilson $(2001,142-3)$. 
there are large clusters around the zero line. In some meta-analyses, just the opposite is found - indicating a bias towards not publishing "null" findings. That does not appear to be the case in this literature. Second, there are a significant number of effect sizes outside the $95 \%$ confidence limits - but they are mostly the larger sample sizes, not an indication of small sample bias. Instead, this is an indication of considerable heterogeneity in study findings - something that is clear from the tables that follow.

\section{B. Why Do Different Studies Obtain Contradictory Findings?}

As shown above, there is considerable heterogeneity in the findings across studies and no dominant pattern. We are equally likely to find a positive, significant result as a negative, significant result - at least in the case of facility, firm or industry-level studies. In the case of state, regional or country-level studies, we are more likely to find a positive relationship - although we are even more likely to find a statistically insignificant relationship. To help understand why this mixed pattern emerges, we return to the theory and empirical evidence summarized in Ambec et al. (2013).

Tables 8 and 9 report on bivariate comparisons of the effect sizes and key variables of interest. Table 8 assumes an equal weight for each effect size within a study (similar to Table 5), while Table 9 uses the preferred specification from each study (similar to Table 6). ${ }^{16}$ First, we separate out the effect sizes by the unit of analysis. For example, as shown in Table 8, out of 70 publications where the unit of analysis was a facility, firm, or industry and we could determine the sign of the

16 Since Tables 8 and 9 report simple bivariate comparisons, the reader is cautioned against drawing any causal inferences from these findings. 
effect size, $46 \%$ were positive. Similarly, as shown in Table 9, when the preferred specification is used, $46 \%$ are positive. However, once the significance level is considered, there is a positive and significant effect in only $29 \%$ of cases and a negative and significant effect in $27 \%$ of cases (with the remaining $44 \%$ finding a statistically insignificant effect). Similar findings are shown in Table 9 using the preferred specification.

As noted earlier, the Porter Hypothesis specifically mentions that flexible regulations are more likely to yield positive innovation offsets. Unfortunately, the form of regulation is rarely specified in published studies, oftentimes because the measures are comprehensive and include all forms of regulation (e.g. pollution abatement and control expenditure or perceived regulatory stringency). In fact, as shown in Table 4, only 7 out of 107 studies described regulatory types that could be considered "command and control" (mostly technology standards or bans), while 32 out of 107 studies described the regulation type as being "flexible" (e.g. emission standards, emissions tax or cap and trade system). The small number of instances where such distinctions could be made makes it particularly difficult to test this important hypothesis. Indeed, as shown in Table 8 while about $50 \%$ of studies with "flexible" regulations have positive results, so do those with command and control regulations. However, when restricted to studies where statistical significance is known and only one preferred specification is used (Table 9), 32\% of effect sizes with flexible regulations are positive and statistically significant, compared to only $7 \%$ of those with command and control regulations. Thus, we are more likely to find 
a positive, statistically significant result when the study examines the impact of flexible regulation as opposed to command and control regulation.

In addition, we note that more flexible and market-based regulations are a relatively newer approach to environmental protection. Thus, one proxy for flexible regulation (especially in studies that rely upon "mixed" types of regulation) might be the time frame of the study data. As shown in Table 3, about 33\% (36/107) of the publications are based on data whose earliest year was 1996 or later. Anecdotal evidence cited in Ambec et al. (2013) suggests that we are more likely to find positive and statistically significant results in these newer studies. However, the data reported on in Tables 8 and 9 are not consistent with this finding. One possible explanation is that because countries have constantly ratcheted up the stringency of regulation over time, the studies with newer data might be reflective of these more stringent regulations. Put differently, studies based on earlier data might be looking at low hanging fruit.

One interesting finding is that studies which mention Porter are less likely to find negative and significant results and more likely to find positive and significant results than studies that do not mention Porter. For example, as shown in Table 8, $59 \%$ of all effect sizes are positive when Porter is mentioned, and $37 \%$ are positive and statistically significant (compared to $17 \%$ that are negative and statistically significant). This result may point to the existence of reporting bias in the sense that studies directly investigating the Porter Hypothesis are more likely to find a positive and significant relationship between environmental regulation and competitiveness relative to studies with an alternative primary research question (Nelson 2011). On 
the other hand, it might simply indicate that authors who find a positive and significant correlation between regulation and competitiveness are more likely to cite Porter as a way to rationalize their otherwise non-intuitive findings.

Table 9 also reports on a statistical test of the hypothesis that preferred effect sizes are equally likely to be positive as negative. ${ }^{17}$ We can reject this hypothesis in only two such comparisons. First, when data is U.S. based, effect sizes are more likely to be negative ( $36 \%$ negative versus $64 \%$ positive, $\mathrm{p}<.05)$. Second, as suggested above, when Porter is mentioned, effect sizes are more likely to be positive ( $59 \%$ positive versus $41 \%$ negative, $\mathrm{p}<.05)$.

Finally, we note the concern in the literature about the possibility of endogeneity and simultaneity with respect to an economy's competitiveness and environmental regulatory stringency (see e.g., Ambec et al., 2013; Brunel and Levinson, 2016). For example, we expect higher demand for environmental protection in wealthier economies. Further, the Porter Hypothesis suggests there is a lag between the time of enactment of environmental regulation, subsequent innovation, and finally observable improvements in competitiveness. Thus, we analyzed the extent to which studies accounted for this lag structure as well as whether or not they attempted to explicitly account for simultaneity through an instrumental variables approach.

As shown in Table 8, only 25\% (27 out of 107) of studies included a lagged regulation variable in their model; and 16\% (17 out of 107) used instrumental

${ }^{17}$ See Bushman and Wang (2009: 209-10). We conduct a nonparametric sign test of the hypothesis that the estimated effect size is greater than 0 . Note that we have not conducted this test for Table 8 because there are many correlated effect sizes within each publication. 
variables as a method to proxy for environmental regulation. The results are again mixed. In particular, we are more likely to find positive effect sizes when studies are based on lagged regulations; whereas negative effect sizes are more likely when using instrumental variables. For example, as shown in Table 9, when restricted to preferred specifications, about 51\% of effect sizes based on lagged regulations are positive (and $49 \%$ are negative, $p>.10$ ); while $36 \%$ are positive and statistically significant compared to only $23 \%$ that are negative and statistically significant. On the other hand, when instrumental variables are used to proxy for environmental regulation, about $40 \%$ of effect sizes are positive (and $60 \%$ are negative, $p>.10$ ); while $37 \%$ are negative and statistically significant compared to only $16 \%$ that are positive and significant. Once again, however, about half of effect sizes are statistically insignificant. While this is a small sample, the findings are similar to the overall results - studies are just as likely to find positive as negative effect sizes, and are more likely to find statistically insignificant results than either positive or negative statistically significant results.

To further investigate the nature of heterogeneity across studies and to control for factors that might affect the sign of the estimated effect sizes, we estimated a series of random effects, weighted meta-regression models with dependent effect size estimates (Hedges, Tipton \& Johnson, 2010). This method (robumeta in STATA) accounts for the fact that the variance estimates of withinstudy effect sizes are not only correlated but likely to be of similar precision due to the fact that effect sizes are likely to have similar sample sizes within study than 
across study. In addition to accounting for within-study effect size correlations, individual effect sizes are weighted by their standard errors.

Table 10 reports on a series of meta-regressions where the dependent variable is defined as the partial correlations. ${ }^{18}$ Model 1 includes only the "flexible regulation" variable, along with an indicator for studies that are conducted at the regional, state or country level (as opposed to firm for facility level). While we find no statistically significant coefficient for the effect of flexible regulation, the region, state or country level coefficient is positive and statistically significant $(\mathrm{p}<.01)$.

Model 2 adds several methodological control variables. First, we include an indicator for whether or not the regulation measure is a lagged variable, an important test of the Porter Hypothesis which predicts a lag from when a regulatory policy is first introduced to when it might induce innovation - ultimately leading to increased competitiveness. While the coefficient on lagged regulation is consistently positive, it is statistically insignificant. Second, as control variables, we include indicators for regression models that include an instrumental variable to account for endogeneity, panel data sets, and the preferred model within each publication. None of these methodological variables are statistically significant, and they do not affect the significance level or signs of the other variables in the model.

${ }^{18}$ Note: we also attempted to estimate this model using elasticities as the effect sizes. While we had 589 elasticity estimates over 44 studies, there were only 91 observations over 13 studies with elasticity variance estimates. This is too small a sample to obtain estimates using robumeta. 
Model 3 adds several control variables that examine the heterogeneity of the Porter Hypothesis studies by country, industry, ${ }^{19}$ year, outcome, and regulatory measures. Once again, none of these control variables are statistically significant, and their inclusion does not affect the other variables in any meaningful way.

\section{Summary of Findings and Concluding Remarks}

This paper reports on a systematic meta-analysis of 107 studies that empirically estimate the relationship between environmental regulation and measures of facility, firm, industry, state, regional or country-level productivity or competitiveness. These 107 studies yielded over 2,000 unique "effect sizes." We find

${ }^{19}$ We have defined "most polluting industries" to include 2-digit SIC codes mining $(10,12,14)$, petroleum $(13,29)$, pulp and paper $(26)$, chemicals $(28)$, iron and steel, non-ferrous metals (33), fabricated metals except machinery and transportation (34), and utilities and waste services (49). Samples that exclude all of these industries are considered "least polluting," with remaining studies being considered "mixed." Although there is no single definition of "pollution intensive" or "dirty" industries, numerous authors have utilized these distinctions in their analysis. Moreover, while there are some differences in definitions, there are also considerable similarities. Jaffe et al. (1995) define pollution-intensive industries based on their abatement cost. For example, while they report PACE as a percentage of total capital expenditures to be $7.5 \%$ overall, four industries had $11 \%$ or more - Paper and Allied Products, Chemical and Allied Products, Petroleum and Coal Products, and Primary Metal Industries (Jaffe et al., Table 6). Fabricated Metal Products was in their "moderate" category (4.35\%), although other authors include this in the "pollution-intensive" sector (see e.g. List and Co, 2000). Similar approaches have been followed by Greenstone (2002) and Morgan and Condliffe (2009), the latter of which have a criterion that to be included in the pollutionintensive industry category, "they emit at least 6 percent of the total sector's emissions of the primary chemical precursors to ozone." Note that our definition of "least polluting" simply means that none of the firms in that category fall within the "most polluting" category. 
considerable heterogeneity in both the sign and significance level of estimated effect sizes across studies. We test the strong form of the Porter Hypothesis - postulating that well designed environmental regulations may lead to innovation that in some cases results in net productivity gains and increased competitiveness. On average, over the 107 studies and 2,025 effect sizes, we find that the relationship between environmental regulation and productivity or competitiveness is about equally likely to be positive as it is negative. However, we also find considerable heterogeneity. These mixed findings have been documented in earlier literature reviews, and contribute to the oftentimes conflicting policy statements we observe about the impact of environmental regulation on firm or country competitiveness.

One relatively consistent finding in our data is that while the likelihood of finding a positive or negative relationship is about equal in the aggregate, we are more likely to find a negative relationship at the facility, firm or industry level and more likely to find a positive relationship at the state, regional or country level. For example, using the preferred specification (Table 9), at the facility, firm or industrylevel, there is more likely to be a negative and statistically significant relationship ( $32 \%$ versus $28 \%$ positive) while at the state, regional or country level, we are more likely to find a positive and statistically significant relationship (32\% versus 14\% negative). In all cases, however, the largest category is "insignificant." To the extent the Porter Hypothesis as originally formulated focused on the competitiveness of 
nations, this finding is particularly interesting and worthy of further exploration (Porter 1991). ${ }^{20}$

The evidence on whether "flexible" regulations such as emission standards, emission fees and cap-and-trade programs are any more or less likely to result in a positive and statistically significant relationship than other regulatory approaches is somewhat mixed. First, we note that differentiating between "flexible" and "command and control" regulation was only possible in about $30 \%$ of the studies (32 out of 107). ${ }^{21}$ Moreover, true market-based regulations (i.e. emission taxes or cap and trade) were identified in only 17 studies. While about half of the studies with flexible regulations show positive results - so do those with command and control regulation. However, when restricted to findings where the level of statistical significance is known, flexible regulations are much more likely to exhibit positive and statistically significant results than command and control regulations.

Finally, studies that include a lagged regulatory variable are more likely to find positive and significant results. This is particularly important in the context of the Porter Hypothesis because it postulates that while there might be short-term costs associated with new regulations, firms will adjust and in the long-term become

\footnotetext{
20 Though a sizable literature investigating the Porter Hypothesis has focused on the impact of environmental regulation on industry and sectoral competitiveness, Porter's original 1991 paper discussed the impact of environmental standards on the competitiveness of American industry in international markets.

${ }^{21}$ One possible avenue for future research is to augment our data with independent assessments of the format of regulation in each study. This would require bringing information and/or expert opinion outside the studies themselves. For example, while a study of water pollution regulation in several European countries might not identify whether the form of regulation was command and control or flexible, legal experts in those countries might be able to classify them accordingly.
} 
more competitive. Thus, a negative contemporaneous and positive long-term relationship is to be expected. 
Ederington \& Minier (2003)

Dutta (2011)

Dufour, Lanoie \& Patray (1998)

Sanchez-Vargas (2013)

Cole, Elliott \& Okubo (2010)

Tobey (1990)

Majumdar \& Marcus (2001)

Li (2012)

Broberg et al. (2013)

Costantini \& Mazzanti (2012)

Rassier \& Earnhart (b) (2010)

Chintrakarn (2008)

Brannlund (2010)

Rennings, \& Rammer (2011)

Gray \& Shadbegian (1993)

Rassier \& Earnhart (a) (2010)

Henderson \& Millimet (2005)

Aichele \& Felbermayr (2010)

Isik (2004)

Grossman \& Krueger (1993)

Fleishman et al. (2009)

Rubashkina, Galeotti \& Verdolini (2015)

Jug (2005)

Keller \& Levinson (2002)

Chakraborty (2011)

King \& Lenox (2001)

Ederington, Levinson \& Minier (2005)

Becker (2011)

Helland \& Matsuno (2003)

Greenstone, List \& Syverson (2012)

Greenstone (2002)

Berman \& Bui (2001)

Arouri et al. (2012)

Groba (2014)

Rutqvist (2009)

Albrizio \& Kozluk (2014)

Rexhauser \& Rammer (2014)

van Leeuwen (2015)

Feres (2012)

van der Vlist, Withagen \& Folmer (2007)

Stam, Herrmann \& Hekkert (2012)

Grether \& De Melo (2004)

Martinez-Zarzoso, Vidovic \& Voicu (2013)

Managi et al. (2005)

Peuckert (2014)

Quiroga, Sterner \& Persson (2009)

Bohringer et al. (2012)

van Beers \& Van Den Bergh (1997)

Managi \& Karemera (2005)

Xu (2000)

Shadbegian \& Gray (2005)

Roediger-Schluga (2003)

Li (2012)

Hamamoto (2006)

Costantini \& Crespi (2008)

Feiock \& Stream (2001)

Renegar (2007)

Costantini \& Crespi (2013)

Cagatay (2006)

Fredriksson, List \& Millimet (2003)

van Beers \& Van Den Bergh (2003)

Ayerbe \& Gorriz (2001)

Zhao (2011)

Murty, Kumar \& Paul (2006)

Albrecht (1999)

Esty \& Porter (2001)

Yang (2010)

Park et al. (2000)

Murty \& Kumar (2003)

Testa, Iraldo \& Frey (2011)

Overall $(\mathrm{I}$-squared $=95.9 \%, p=0.000)$

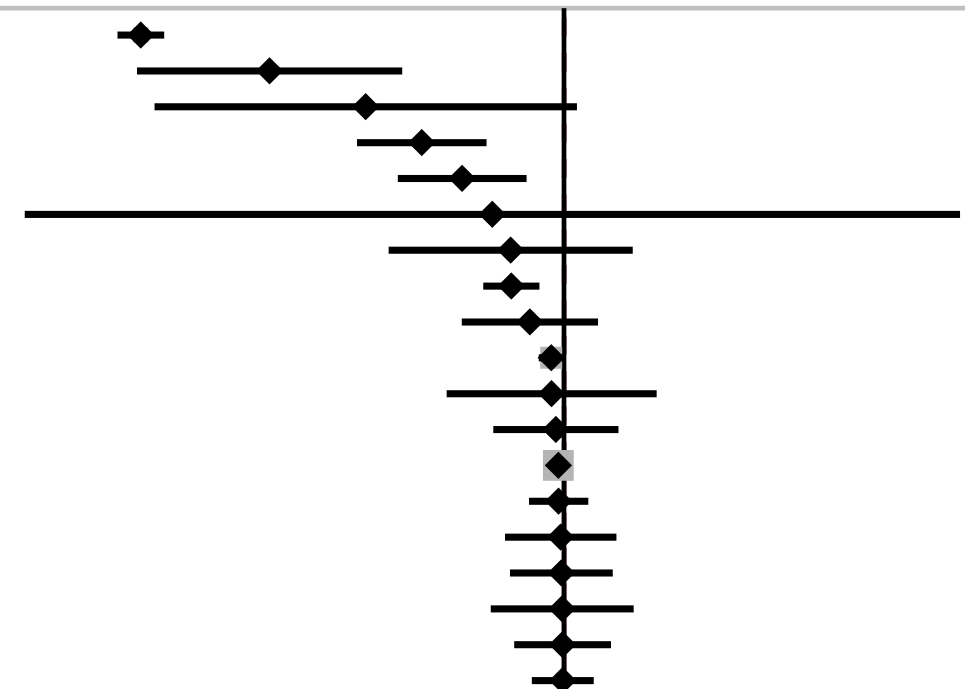

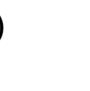


Figure 2

Funnel Plot of Partial Correlations

(full sample)

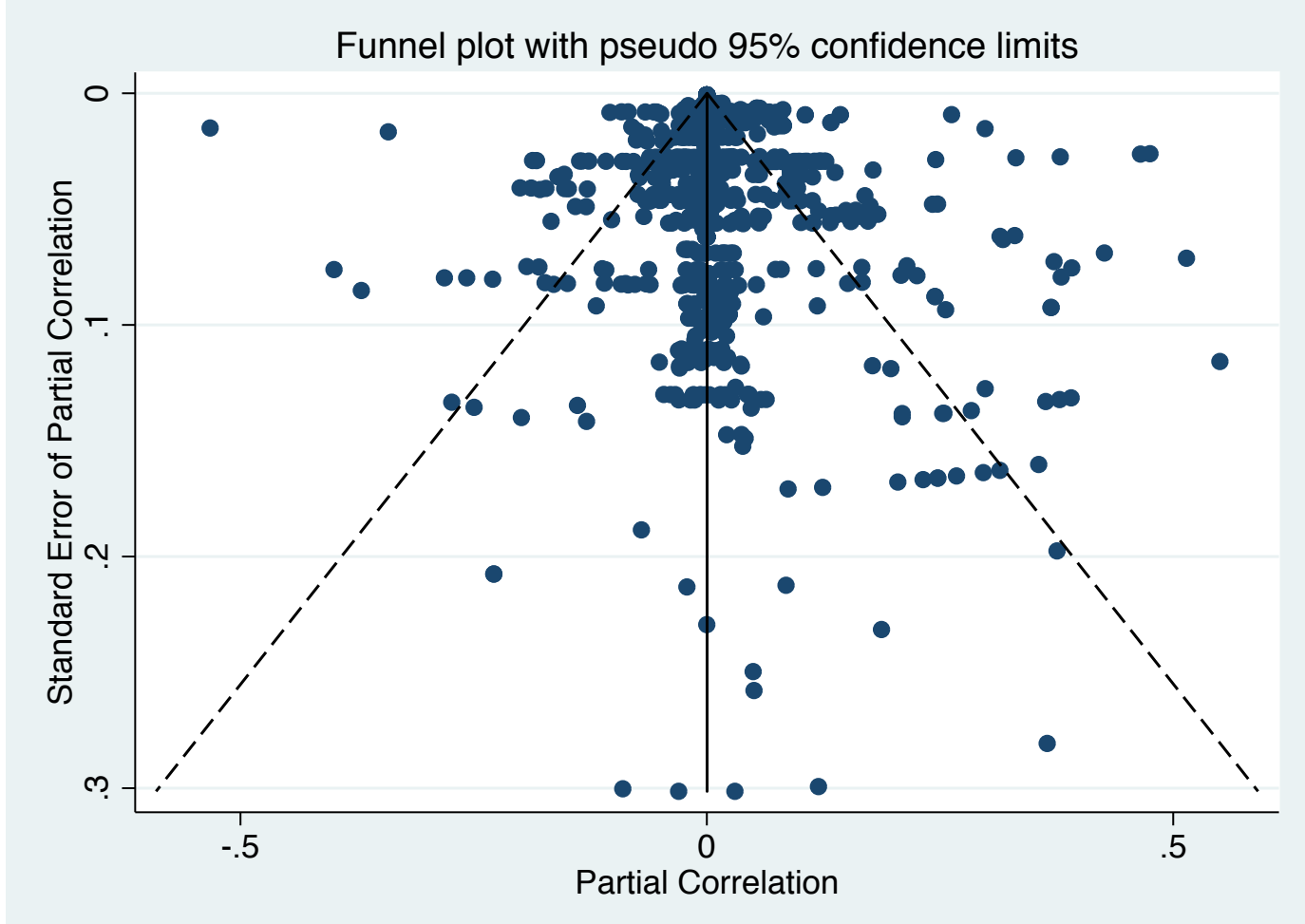


Figure 3

Funnel Plot of Partial Correlations

(preferred specifications only)

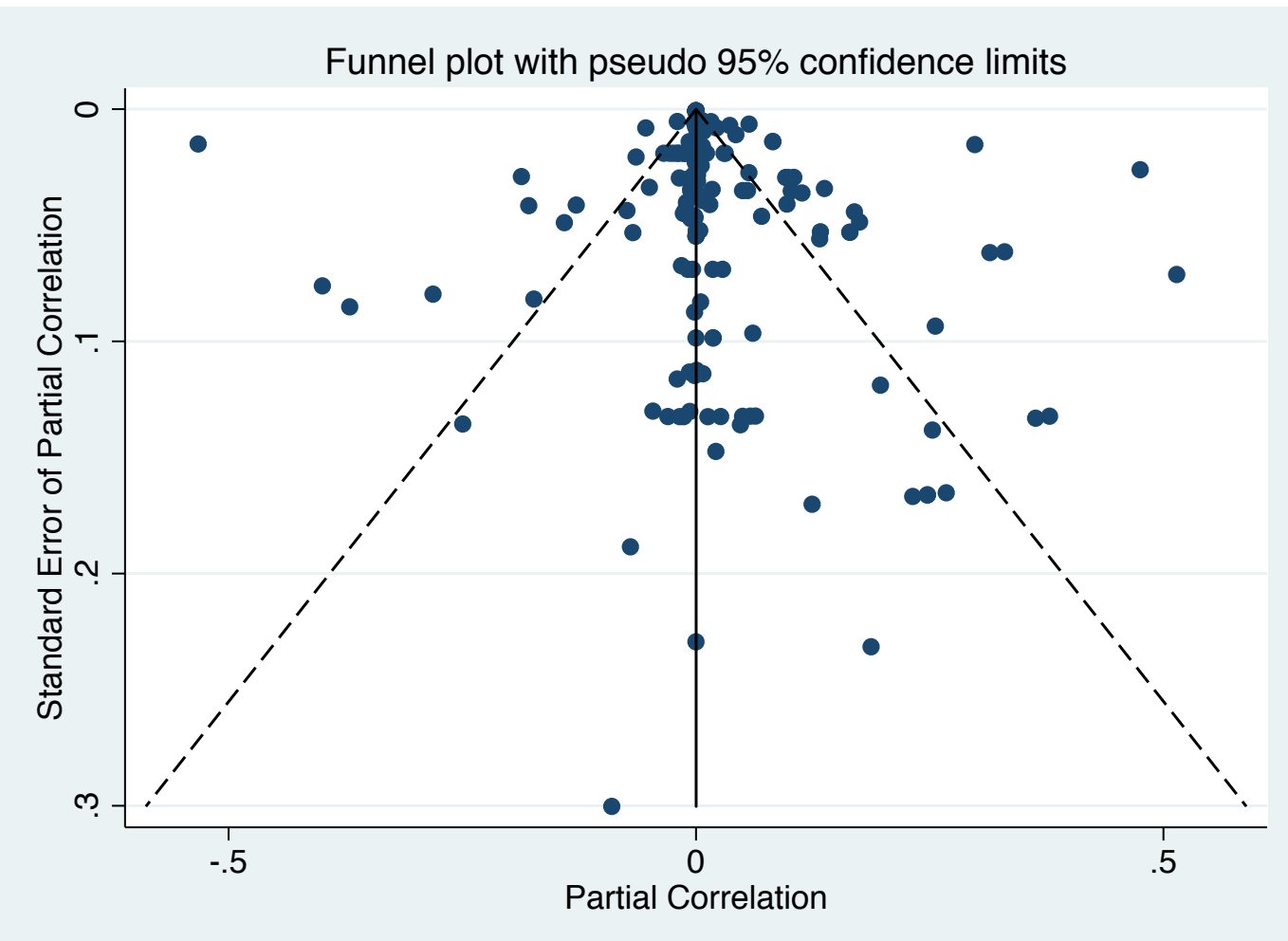


Table 1

Disposition of Research Publications During Search Process

\begin{tabular}{|l|c|}
\hline & Number \\
\hline Total papers reviewed & 1,055 \\
\hline & \\
\hline Empirical papers related to PH & 649 \\
\hline - Not eligible: Literature reviews & 14 \\
\hline - Not eligible: Voluntary programs & 27 \\
\hline - Not eligible: Ineligible empirical methodology & 165 \\
\hline - Not eligible: Other (no outcome measure related to PH) & 339 \\
\hline - Eligible publications & 103 \\
\hline
\end{tabular}


Table 2

Number of Studies, Effect Sizes \& Elasticity Estimates by Outcome Measures (107 studies that include productivity or competitiveness measures)

\begin{tabular}{|l|c|c|c|c|}
\hline & \multicolumn{2}{l|}{ Studies } & \multicolumn{2}{l|}{$\begin{array}{l}\text { Studies with Elasticity } \\
\text { Estimates }\end{array}$} \\
\hline & Number & $\begin{array}{l}\text { \# Effect } \\
\text { Sizes }\end{array}$ & Number & $\begin{array}{l}\text { \# Elasticity } \\
\text { Estimates }\end{array}$ \\
\hline $\begin{array}{l}\text { Facility/firm/ } \\
\text { industry-level }\end{array}$ & 70 & 1,059 & 33 & 313 \\
\hline - Facility/firm & $(45)$ & $(749)$ & $(22)$ & $(222)$ \\
\hline - Industry & $(25)$ & $(310)$ & $(11)$ & $(101)$ \\
\hline $\begin{array}{l}\text { State/regional or } \\
\text { country-level }\end{array}$ & 37 & 966 & 13 & 334 \\
\hline Combined & 107 & 2,025 & 47 & 647 \\
\hline
\end{tabular}


Table 3

Publication-level Characteristics

\begin{tabular}{|c|c|c|c|}
\hline & $\begin{array}{l}\text { Facility, Firm } \\
\text { or Industry }\end{array}$ & $\begin{array}{l}\text { State, Regional } \\
\text { or Country }\end{array}$ & Combined \\
\hline Earliest Year of Data & \multicolumn{3}{|c|}{ Number of Publications } \\
\hline Prior to 1976 & 11 & 5 & 16 \\
\hline 1976-1980 & 8 & 5 & 13 \\
\hline 1981-1985 & 5 & 3 & 8 \\
\hline 1986-1990 & 11 & 5 & 16 \\
\hline 1991-1995 & 12 & 6 & 18 \\
\hline $1996-2000$ & 12 & 11 & 23 \\
\hline $2001-2005$ & 9 & 2 & 11 \\
\hline \multirow[t]{2}{*}{$2006+$} & 2 & - & 2 \\
\hline & 70 & 37 & 107 \\
\hline \multicolumn{4}{|l|}{ Year of Publication } \\
\hline 1980-1985 & 2 & - & 2 \\
\hline 1986-1990 & 2 & 1 & 2 \\
\hline 1991-1995 & 2 & 2 & 4 \\
\hline 1996-2000 & 2 & 5 & 7 \\
\hline $2001-2005$ & 19 & 10 & 30 \\
\hline $2006-2010$ & 20 & 8 & 28 \\
\hline \multirow[t]{2}{*}{ 2011-2015 } & 23 & 12 & 35 \\
\hline & 70 & 37 & 107 \\
\hline \multicolumn{4}{|l|}{ Mention Porter? } \\
\hline Yes & 48 & 21 & 69 \\
\hline \multicolumn{4}{|l|}{ Country } \\
\hline OECD only & 10 & 7 & 17 \\
\hline $\begin{array}{l}\text { Europe (including } \\
\text { countries outside EU) }\end{array}$ & 1 & 1 & 2 \\
\hline EU only & 22 & 3 & 25 \\
\hline US only & 23 & 14 & 37 \\
\hline Global & 3 & 9 & 12 \\
\hline Other single country & 9 & 2 & 11 \\
\hline Total & 70 & 37 & 107 \\
\hline \multicolumn{4}{|l|}{ Funding Source } \\
\hline NSF-type source & 17 & 9 & 26 \\
\hline Business/commerce & 5 & 2 & 7 \\
\hline Environmental & 13 & 4 & 17 \\
\hline No funding mentioned & 35 & 22 & 57 \\
\hline Total & 70 & 37 & 107 \\
\hline
\end{tabular}


Table 4

Environmental Regulation Characteristics

\begin{tabular}{|l|c|c|c|}
\hline & $\begin{array}{l}\text { Facility, Firm or } \\
\text { Industry-level }\end{array}$ & $\begin{array}{l}\text { State, Regional } \\
\text { or } \\
\text { level }\end{array}$ & Country- \\
\hline Type of Regulation & 7 & 0 & \\
\hline Command and control & 25 & 7 & 7 \\
\hline Flexible & 5 & 8 & 32 \\
\hline - Emission tax & 2 & 2 & 13 \\
\hline - Cap \& trade & & & 4 \\
\hline Media & 11 & 4 & 10 \\
\hline Air (other than GHG) & 6 & 4 & 3 \\
\hline $\begin{array}{l}\text { Greenhouse gas } \\
\text { emissions }\end{array}$ & 2 & 1 & 6 \\
\hline Energy efficiency & 6 & 0 & 18 \\
\hline Waste & 14 & 4 & 8 \\
\hline Water & 5 & 3 & 47 \\
\hline $\begin{array}{l}\text { Other (land, pesticides, } \\
\text { etc.) }\end{array}$ & 70 & 37 & 107 \\
\hline Unknown or more than 3 & & & \\
\hline Total & 26 & & \\
\hline
\end{tabular}

Note: If a publication contains more than one type of regulation or one media, each one that appears is counted as being in the publication. 
Table 5

Direction of the Relationship between Environmental Regulation and Financial Outcomes

\begin{tabular}{|l|c|c|c|c|c|c|}
\hline & $\begin{array}{l}\text { Facility, Firm or } \\
\text { Industry-level }\end{array}$ & $\begin{array}{l}\text { State, Regional or } \\
\text { Country-level }\end{array}$ & Combined \\
\hline \multicolumn{7}{|c|}{ All Specifications } \\
\hline & Number & $\%$ & Number & $\%$ & Number & $\%$ \\
\hline Negative & 37.9 & $54 \%$ & 15.9 & $43 \%$ & 53.1 & $50 \%$ \\
\hline Positive & 32.1 & $46 \%$ & 21.1 & $57 \%$ & 53.9 & $50 \%$ \\
\hline \# publications & 70 & $100 \%$ & 37 & $100 \%$ & 107 & $100 \%$ \\
\hline \multicolumn{7}{|c|}{ Preferred Specifications } \\
\hline & Number & $\%$ & Number & $\%$ & Number & $\%$ \\
\hline Negative & 37.5 & $54 \%$ & 17.0 & $45.8 \%$ & 54.5 & $52 \%$ \\
\hline Positive & 31.5 & $45 \%$ & 20.0 & $54.2 \%$ & 51.5 & $48 \%$ \\
\hline \# publications & 69 & $100 \%$ & 37 & $100 \%$ & 106 & $100 \%$ \\
\hline
\end{tabular}


Table 6

Percent of Effect Sizes that are Significant \& Direction Relationship between Environmental Regulation \& Financial Outcomes

\begin{tabular}{|l|c|c|c|}
\hline & $\begin{array}{l}\text { Firm or Facility- } \\
\text { level Productivity } \\
\text { or Profitability }\end{array}$ & $\begin{array}{l}\text { State, Regional or } \\
\text { Country-level } \\
\text { Competitiveness }\end{array}$ & Combined \\
\hline \multicolumn{3}{|c|}{ All Specifications } \\
\hline Negative, Sig. & $27 \%$ & $12 \%$ & $22 \%$ \\
\hline Insignificant & $46 \%$ & $60 \%$ & $51 \%$ \\
\hline Positive, Sig. & $27 \%$ & $28 \%$ & $27 \%$ \\
\hline \# publications & 67 & 36 & 103 \\
\hline & \multicolumn{2}{|c|}{ Preferred Specifications } \\
\hline Negative, Sig. & $32 \%$ & $14 \%$ & $26 \%$ \\
\hline Insignificant & $40 \%$ & $54 \%$ & $29 \%$ \\
\hline Positive, Sig. & $28 \%$ & $32 \%$ & 101 \\
\hline \# publications & 65 & 36 & \\
\hline
\end{tabular}


Table 7

Estimated Elasticity of Competitiveness, Profit, and Productivity on Environmental Regulation

\begin{tabular}{|c|c|c|c|c|c|}
\hline \multirow[b]{2}{*}{ Dependent Variable } & \multirow[b]{2}{*}{$\begin{array}{l}\text { Elasticity } \\
\text { Range }\end{array}$} & \multicolumn{2}{|c|}{$\begin{array}{c}\text { All } \\
\text { Specifications }\end{array}$} & \multicolumn{2}{|c|}{$\begin{array}{c}\text { Preferred } \\
\text { Specifications }\end{array}$} \\
\hline & & $\begin{array}{c}\# \\
\text { Pubs }\end{array}$ & $\begin{array}{c}\text { Elast. } \\
{[95 \% \mathrm{CI}]}\end{array}$ & $\begin{array}{c}\# \\
\text { Pubs }\end{array}$ & $\begin{array}{c}\text { Elast. } \\
{[95 \% \mathrm{CI}]}\end{array}$ \\
\hline Combined & $-4.47,+4.38$ & 46 & $\begin{array}{c}+.15 \\
{[+.08,+.22]}\end{array}$ & 41 & $\begin{array}{c}+.11 \\
{[-.11,+.32]}\end{array}$ \\
\hline - Competitiveness & $-4.12,+4.38$ & 16 & $\begin{array}{c}+.20 \\
{[+.08,+.33]}\end{array}$ & 13 & $\begin{array}{c}+.23 \\
{[-.20,+.67]}\end{array}$ \\
\hline - Profit & $-2.32,+0.55$ & 12 & $\begin{array}{c}-.02 \\
{[-.05,+.01]}\end{array}$ & 12 & $\begin{array}{c}-.03 \\
{[-.08,+.01]}\end{array}$ \\
\hline - Output/productivity & $-4.47,+3.36$ & 18 & $\begin{array}{c}+.22 \\
{[+.07,+.37]}\end{array}$ & 16 & $\begin{array}{c}+.02 \\
{[-.45,+.49]}\end{array}$ \\
\hline
\end{tabular}

Note: The first row represents all dependent variable specifications. The second row restricts the sample to effect sizes where the dependent variable was a measure of competitiveness. The third row represents effect sizes that measure profits or firm valuation, while the last row represents effect sizes that measure output or productivity. Outliers (29 cases out of 647 with an elasticity of greater than 5 in absolute value) have been eliminated. In some cases, there were multiple elasticities within the preferred model specification. This might occur because there was either more than one environmental regulation variable in a regression model, or there were two different subsamples being used in a study, and both were determined to be preferred specifications. In cases with multiple "preferred specification" elasticities, all such estimates within that study were given equal weight. However, all effect sizes have also been weighted by the square root of the number of observations that were used in the model which estimated that particular effect size. 
Table 8

Bivariate Comparisons

(Equally weighted effect sizes within each publication)

\begin{tabular}{|c|c|c|c|c|c|c|}
\hline & \multicolumn{2}{|c|}{ Full sample } & \multicolumn{4}{|c|}{ Significance level known } \\
\hline & $\mathrm{N}$ & $\begin{array}{l}\% \\
\text { Positive }\end{array}$ & $\mathrm{N}$ & $\begin{array}{l}\text { \% } \\
\text { Negative } \\
\text { Significant }\end{array}$ & $\begin{array}{l}\text { \% } \\
\text { Insignif. }\end{array}$ & $\begin{array}{l}\% \text { Positive } \\
\text { Significant }\end{array}$ \\
\hline \multicolumn{7}{|l|}{ Level of Analysis } \\
\hline - Facility, firm or industry & 70 & $46 \%$ & 70 & $27 \%$ & $44 \%$ & $29 \%$ \\
\hline - Facility or firm & 45 & 47 & 45 & 25 & 47 & 28 \\
\hline - Industry or sector & 25 & 43 & 25 & 30 & 36 & 33 \\
\hline - State, region or country & 37 & 57 & 37 & 12 & 59 & 29 \\
\hline \multicolumn{7}{|l|}{ Type of Regulation } \\
\hline - Command \& control & 7 & 52 & 7 & 28 & 46 & 25 \\
\hline - Flexible & 32 & 47 & 32 & 28 & 40 & 32 \\
\hline - Emission standard & 15 & 33 & 15 & 31 & 49 & 20 \\
\hline - Emission tax & 9 & 56 & 9 & 18 & 57 & 25 \\
\hline - Cap \& trade & 4 & 58 & 4 & 15 & 35 & 50 \\
\hline - Mixed/unknown & 81 & 51 & 81 & 17 & 53 & 29 \\
\hline \multicolumn{7}{|l|}{ Regulatory Measure } \\
\hline - Abatement costs & 51 & 46 & 51 & 23 & 48 & 29 \\
\hline - Regulatory stringency & 46 & 52 & 46 & 21 & 54 & 25 \\
\hline - Enforcement & 13 & 52 & 13 & 16 & 58 & 26 \\
\hline - Government R\&D & 3 & 100 & 3 & 0 & 13 & 87 \\
\hline - Emissions as proxy & 3 & 84 & 3 & 7 & 21 & 72 \\
\hline \multicolumn{7}{|l|}{ Other Controls } \\
\hline - U.S. data & 37 & 36 & 37 & 28 & 57 & 15 \\
\hline - Start year >=1996 & 36 & 57 & 36 & 23 & 49 & 28 \\
\hline - Porter mentioned & 69 & 59 & 69 & 17 & 46 & 37 \\
\hline \multicolumn{7}{|l|}{ Modeling Strategy } \\
\hline - Instrumental variables & 17 & 37 & 17 & 35 & 49 & 16 \\
\hline $\begin{array}{l}\text {-Lagged regulation } \\
\text { variable }\end{array}$ & 27 & 53 & 27 & 17 & 45 & 37 \\
\hline
\end{tabular}


Table 9

Bivariate Comparisons

(One preferred specification per publication)

\begin{tabular}{|c|c|c|c|c|c|c|}
\hline & \multicolumn{2}{|c|}{ Full sample } & \multicolumn{4}{|c|}{ Significance level known } \\
\hline & $\mathrm{N}$ & $\begin{array}{l}\% \\
\text { Positive }\end{array}$ & $\mathrm{N}$ & $\begin{array}{l}\% \\
\text { Negative } \\
\text { Significant }\end{array}$ & $\begin{array}{l}\text { \% } \\
\text { Insignif. }\end{array}$ & $\begin{array}{l}\text { \% Positive } \\
\text { Significant }\end{array}$ \\
\hline \multicolumn{7}{|l|}{ Level of Analysis } \\
\hline - Facility, firm or industry & 69 & $46 \%$ & 65 & $32 \%$ & $46 \%$ & $28 \%$ \\
\hline - Facility or firm & 45 & 47 & 43 & 34 & 42 & 24 \\
\hline - Industry or sector & 24 & 43 & 22 & 28 & 36 & 35 \\
\hline - State, region or country & 37 & 54 & 36 & 14 & 54 & 32 \\
\hline \multicolumn{7}{|l|}{ Type of Regulation } \\
\hline - Command \& control & 7 & 50 & 7 & 36 & 57 & 7 \\
\hline - Flexible & 32 & 50 & 29 & 31 & 37 & 32 \\
\hline - Emission standard & 15 & 36 & 13 & 33 & 52 & 15 \\
\hline - Emission tax & 8 & 62 & 7 & 21 & 36 & 43 \\
\hline - Cap \& trade & 4 & 38 & 4 & 25 & 38 & 38 \\
\hline - Mixed/unknown & 77 & 49 & 74 & 22 & 47 & 31 \\
\hline \multicolumn{7}{|l|}{ Regulatory Measure } \\
\hline - Abatement costs & 50 & 43 & 48 & 29 & 40 & 30 \\
\hline - Regulatory stringency & 44 & 53 & 42 & 25 & 51 & 24 \\
\hline - Enforcement & 11 & 54 & 10 & 20 & 47 & 33 \\
\hline - Government R\&D & 3 & 100 & 3 & 0 & 0 & 100 \\
\hline - Emissions as proxy & 3 & 83 & 3 & 3 & 23 & 73 \\
\hline \multicolumn{7}{|l|}{ Other Controls } \\
\hline - U.S. data & 37 & $36^{* *}$ & 34 & 36 & 51 & 13 \\
\hline - Start year >=1996 & 36 & 55 & 36 & 25 & 45 & 30 \\
\hline - Porter mentioned & 69 & $59^{* *}$ & 66 & 19 & 44 & 37 \\
\hline \multicolumn{7}{|l|}{ Modeling Strategy } \\
\hline - Instrumental variables & 17 & 40 & 17 & 37 & 47 & 16 \\
\hline $\begin{array}{l}\text { - Lagged regulation } \\
\text { variable }\end{array}$ & 23 & 51 & 21 & 23 & 41 & 36 \\
\hline
\end{tabular}

${ }^{* *} \mathrm{p}<.05$, testing the hypothesis that $\mathrm{p}($ positive $)=\mathrm{p}$ (negative $)$

Note: Although this table is restricted to one preferred specification per study, some specifications include more than one environmental regulation measure as an independent variable. Thus, for example, one regression equation might have two environmental regulation variables with one having a positive coefficient and one being negative. In some cases, there is also more than one "preferred" specification for example, in a publication where only three subsamples are reported and no full sample estimates are made, all three subsamples might be considered preferred and be equally weighted. 
Table 10: Meta-Regression

Dependent Variable: Partial Correlations

\begin{tabular}{|c|c|c|c|}
\hline & Model 1 & Model 2 & Model 3 \\
\hline Region/state/country & $.045^{* * *}$ & $.059 * * *$ & $.052 * * *$ \\
\hline Flexible regulation & -.006 & -.011 & -.018 \\
\hline \multicolumn{4}{|c|}{ Methodological Variables } \\
\hline Lag regulation & & .015 & .020 \\
\hline Instrumental var. & & -.069 & -.075 \\
\hline Panel data & & -.020 & -.023 \\
\hline Preferred model & & .010 & -.05 \\
\hline \multicolumn{4}{|l|}{ Sample Characteristics } \\
\hline US only & & & -.0006 \\
\hline OECD & & & .049 \\
\hline EU & & & .001 \\
\hline Start year >1996 & & & .002 \\
\hline Most polluting & & & .027 \\
\hline Least polluting & & & .056 \\
\hline \multicolumn{4}{|l|}{ Outcome Measure } \\
\hline Output & & & .011 \\
\hline \multicolumn{4}{|l|}{ Regulation Measure } \\
\hline Cost & & & -.004 \\
\hline Stringency & & & .019 \\
\hline Enforcement & & & .029 \\
\hline Emissions proxy & & & .155 \\
\hline Constant & -.003 & .022 & -.014 \\
\hline $\mathrm{N}$ & 1303 & 1303 & 1303 \\
\hline
\end{tabular}

${ }^{*} \mathrm{p}<.10$; $^{* *} \mathrm{p}<.05$;** $\mathrm{p}<.01$ 


\section{References}

Ambec, Stefan, Mark A. Cohen, Stewart Elgie, and Paul Lanoie. 2013. The Porter Hypothesis at 20: Can Environmental Regulation Enhance Innovation and Competitiveness?. Review of Environmental Economics \& Policy 7 (1): 2-22.

Berman, E., and L.T.M. Bui. 2001. Environmental Regulation and Productivity: Evidence from Oil Refineries. Review of Economics and Statistics 83 (3): 498-510.

Brunel, Claire and Arik Levinson. 2016. Measuring the Stringency of Environmental Regulations. Review of Environmental Economics and Policy 10 (1): 47-67.

Brunnermeier, Smita G. and Arik Levinson. 2004. Examining the Evidence on Environmental Regulations and Industry Location. Journal of Environment \& Development 13 (6): 6-41.

Bushman, Brad J. and Morgan C. Wang. 2009. Vote-Counting Procedures in MetaAnalysis. Chapter in The Handbook of Research Synthesis \& Meta-Analysis, 2nd Ed. (Harris Cooper, Larry V. Hedges, and Jeffrey C. Valentine, eds.). New York: Russell Sage Foundation.

Copeland, Brian R. and Michael S. Taylor. 2004. Trade, Growth and the Environment. Journal of Economic Literature 42: 7-71.

Egger, Matthias. 1997. Bias in Meta-Analysis Detected by a Simple Graphical Test. British Medical Journal 315: 629-34.

Greenstone, Michael. 2002. The Impacts of Environmental Regulations on Industrial Activity: Evidence from the 1970 \& 1977 Clean Air Act Amendments and the Census of Manufacturers. Journal of Political Economy 110 (6): 1175-1219.

Harbord, Roger M. and Julian P.T. Higgins. 2008. Meta-regression in Stata. Stata Journal 8 (4): 493-519.

Hedges, Larry V., Elizabeth Tipton, and Matthew C. Johnson. 2010. Robust variance estimation in meta-regression with dependent effect size estimates. Research Synthesis Methods. (www.interscience.wiley.com) DOI: 10.1002/jrsm.

Horváthová, Eva. 2010. Does Environmental Performance Affect Financial Performance? A Meta-analysis. Ecological Economics 70: 52-9. 
Iraldo, Fabio, Francesco Testa, Michela Melis, and Marco Frey. 2011. A Literature Review on the Links between Environmental Regulation and Competitiveness. Environmental Policy and Governance 21 (3): 210-22.

Jaffe, Adam B., and Karen Palmer. 1997. Environmental Regulation and Innovation: A Panel Data Study. Review of Economics and Statistics 79 (4): 610-619.

Jaffe, Adam B., Steven R. Peterson, Paul R. Portney, and Robert N. Stavins. 1995. Environmental Regulation and International Competitiveness: What Does the Evidence Tell Us? Journal of Economic Literature 93: 658-712.

Lankoski, Leena. 2010. Linkages between Environmental Policy and Competitiveness, OECD Environment Working Papers No. 13, www.oecd.org/dataoecd/0/8/44392874.pdf.

Lanoie, P., M. Patry, and R. Lajeunesse. 2008. Environmental Regulation and Productivity: New Findings on the Porter Hypothesis. Journal of Productivity Analysis 30: 121-128.

Lipsey, Mark W. and David B. Wilson. 2001. Practical Meta-Analysis. Applied Social Research Methods Series, Sage Publications, Thousand Oaks, California.

List, John A. and Catherine Y. Co. 2000. The Effects of Environmental Regulations on Foreign Direct Investment. Journal of Environmental Economics and Management 40: 1-20.

Morgan, O. Ashton and Simon Condliffe. 2009. Spatial Heterogeneity in Environmental Regulation Enforcement and the Firm Location Decision among U.S. Counties. The Review of Regional Studies 39 (3): 239-52.

Nelson, Jon P. and Peter E. Kennedy. 2009. The Use (and Abuse) of Meta-analysis in Environmental and Natural Resource Economics: An Assessment. Environmental \& Resource Economics 42 (3): 345-377.

Nelson, Jon P. 2011. Alcohol Marketing, Adolescent Drinking and Publication Bias in Longitudinal Studies: A critical survey using meta-analysis. Journal of Economic Surveys 25 (2): 191-232.

Nelson, Jon P. 2013. Meta-analysis of alcohol price and income elasticities - with corrections for publication bias. Health Economics Review 3:17. 
Palmer, Karen, Wallace E. Oates, and Paul R. Portney. 1995. Tightening Environmental Standards: The Benefit-Cost or the No-Cost Paradigm? Journal of Economic Perspectives 9 (4): 119-132.

Porter, Michael. 1991. America’s Green Strategy. Scientific American 264 (4): 168.

Porter, Michael and Claus van der Linde. 1995. Toward a New Conception of the Environment-Competitiveness Relationship. Journal of Economic Perspective 9 (4): 97-118.

Stanley, Tom D. 2005. Beyond Publication Bias. Journal of Economic Surveys 19 (3): 309-345.

Stanley, Tom D. 2013. Does economics add up? An introduction to meta-regression analysis. European Journal of Economics and Economic Policies: Intervention 10 (2): 207-220.

Stanley, Tom D. and Hristos Doucouliagos. 2012. Meta-Regression Analysis in Economics and Business, $1^{\text {st }}$ Ed. New York: Routledge.

Sterne, Jonathan A.C. and Roger M. Harbord. 2004. Funnel plots in meta-analysis. The Stata Journal 4 (2): 127-141.

Sterne, Jonathan A.C. and Matthias Egger. 2001. Funnel plots for detecting bias in metaanalysis: guidelines on choice of axis. Journal of Clinical Epidemiology 54 (10): 1046-1055. 


\section{Appendix A \\ 103 Publications in Meta-Analysis}

1. Aichele, R., Felbermayr, G. Kyoto and the carbon content of trade. 2010. FZID discussion papers.

2. Albrecht, J.A., 1999. Environmental costs and competitiveness. A productspecific test of the porter hypothesis. International Journal of Development Planning Literature 219-231.

3. Albrizio, S., Kozluk, T., 2014. Does Environmental Policy Stringency Affect Industry Productivity Growth? Working Paper.

4. Arouri, M., Caporale, G.M., Rault, C., Sova, R., Sova, A., 2012. Environmental Regulation and Competitiveness: Evidence from Romania. Ecological Economics 130139.

5. Ayerbe, C.G., Gorriz, C.G., 2001. The effects of environmental regulations on the productivity of large companies: an empirical analysis of the Spanish case. Journal of Management and Governance 5, 129-152.

6. Barbera, A.J., McConnell, V.D., 1986. Effects of pollution control on industry productivity: a factor demand approach. The Journal of Industrial Economics 161-172.

7. Becker, R.A., 2011. Local environmental regulation and plant-level productivity. Ecological Economics 2516-2522.

8. Berman, E., Bui L.T.M., 2001. Environmental regulation and labor demand: Evidence from the south coast air basin. Journal of Public Economics 79, 265-295.

9. Bokusheva, R., Kumbhakar, S.C., Lehmann, B., 2012. The effect of environmental regulations on Swiss farm productivity. International Journal of production economics 93-101.

10. Bohringer C., Moslener U., Oberndorfer, U., Ziegler A., 2012. Clean and productive? Empirical evidence from the German manufacturing industry. Research Policy 41, 442-451.

11. Brannlund, R., Lundgren, T., 2010. Environmental policy and profitability: evidence from Swedish industry. Environmental Economics and Policy Studies 12, 5978.

12. Broberg, T., Marklund, P., Samakovlis, E., Hammar, H., 2013. Testing the Porter hypothesis: the effects of environmental investments on efficiency in Swedish industry. Journal of Productivity Analysis 43-56. 
13. Cagatay, S., Mihci, H., 2006. Degree of environmental stringency and the impact on trade patterns. Journal of economic studies 33, 30-51.

14. Cave, L.A., Blomquist, G.C., 2008. Environmental policy in the European Union: Fostering the development of pollution havens? Ecological Economics 65, 253-261.

15. Chakraborty, P., 2011. Environmental Standards and Trade: Evidence from Indian Textile \& Leather Industry. Working paper.

16. Chintrakarn, P., 2008. Environmental regulation and US states' technical inefficiency. Economics Letters 100, 363-365.

17. Cole, E.T., Ensign, P.C., 2005. An examination of US FDI into Mexico and its relation to NAFTA: understanding the effects of environmental regulation and the factor endowments that affect the location decision. The International Trade Journal 19, 1-30.

18. Cole, M.A., Elliott, R.J.R., Okubo, T., 2010. Trade, environmental regulations and industrial mobility: An industry-level study of Japan. Ecological Economics 69, 1995-2002.

19. Costantini, V., Crespi, F., 2008. Environmental regulation and the export dynamics of energy technologies. Ecological Economics 66, 447-460.

20. Costantini, V., Mazzanti, M., 2012. On the green and innovative side of trade competitiveness? The impact of environmental policies and innovation on EU exports. Research Policy 41, 132-153.

21. Costantini, V., Crespi, F., 2013. Public policies for a sustainable energy sector: regulation, diversity and fostering of innovation. Journal of Evolutionary Economics 401429.

22. Darnall, N., 2009. Regulatory stringency, green production offsets, and organizations' financial performance. Public Administration Review 69, 418-434.

23. De Santis, R., 2012. Impact of Environmental Regulations on Trade in the Main EU Countries: Conflict or Synergy? The World Economy 799-815.

24. Dufour, C., Lanoie, P., Patry, M., 1998. Regulation and Productivity. Journal of Productivity Analysis 233-247.

25. Dutta, N., Narayanan, K., 2011. Impact of Environmental Regulation on Technical Efficiency. Science Technology \&amp; Society 16, 333-350.

26. Ederington, J., Minier, J., 2003. Is environmental policy a secondary trade barrier? An empirical analysis. Canadian Journal of Economics 36, 137-154. 
27. Ederington, J., Levinson, A., Minier, J., 2005. Footloose and Pollution Free. The Review of Economics and Statistics 87, 92-99.

28. Esty, D.C., Porter, M.E., 2001. Ranking national environmental regulation and performance: a leading indicator of future competitiveness? The global competitiveness report 2001-2002 78-100.

29. Feiock, R.C., Stream, C., 2001. Environmental Protection Versus Economic Development: A False Trade-Off? Public Administration Review 61, 313-321.

30. Feres, J., Reynaud, A., 2012. Assessing the Impact of Formal and Informal Regulations on Environmental and Economic Performance of Brazilian Manufacturing Firms. Environmental and Resource Economics 65-85.

31. Fleishman, R., Alexander, R., Bretschneider, S., Popp, D., 2009. Does regulation stimulate productivity? The effect of air quality policies on the efficiency of US power plants. Energy Policy 37, 4574-4582.

32. Fredriksson, P.G., List, J.A., Millimet, D.L., 2003. Bureaucratic corruption, environmental policy and inbound US FDI: theory and evidence. Journal of Public Economics 87, 1407-1430.

33. Garofalo, G.A., Malhotras, D.M., 1995. Effect of Environmental Regulations on State-level Manufacturing Capital Formation. Journal of Regional Science 35, 201-216.

34. Gollop, F.M., Roberts, M.J., 1983. Environmental Regulations and Productivity Growth: The Case of Fossil-fueled Electric Power Generation. Journal of Political Economy 654-674.

35. Gray, W.B., 1987. The cost of regulation: OSHA, EPA and the productivity slowdown. The American Economic Review 998-1006.

36. Gray, W.B., Shadbegian, R.J. Environmental regulation and manufacturing productivity at the plant level. 1993. National Bureau of Economic Research.

37. Gray, W.B., Shadbegian, R.J., 2003. Plant vintage, technology, and environmental regulation. Journal of Environmental Economics and Management 46, 384-402.

38. Greenstone, M., 2002. The Impacts of Environmental Regulations on Industrial Activity: Evidence from the 1970 \& 1977 Clean Air Act Amendments and the Census of Manufactures. Journal of Political Economy 1175-1219.

39. Greenstone, M., List, J.A., Syverson, C. 2012. The Effects of Environmental Regulation on the Competitiveness of US Manufacturing. National Bureau of Economic Research. 
40. Grether, J.M., De Melo, J., 2004. Globalization and dirty industries: Do pollution havens matter? in Challenges to Globalization : Analyzing the Economics (Robert E. Baldwin and Alan L. Winters, eds.). University of Chicago Press, pp. 167-203.

41. Groba, F., 2014. Determinants of trade with solar energy technology components: evidence on the porter hypothesis? Applied Economics 503-526.

42. Grossman, G.M., Krueger, A.B. 1993. Environmental Impacts of a North American Free Trade Agreement.. M.I.T Press. The Mexico-U.S. Free Trade Agreement.

43. Hackenbruck, S. 2005. How environmental regulations affect productivity of US and Mexican primary iron \& steel and aluminum industries. Dissertation.

44. Hamamoto, M., 2006. Environmental regulation and the productivity of Japanese manufacturing industries. Resource and energy economics 28, 299-312.

45. Helland, E., Matsuno, M., 2003. Pollution abatement as a barrier to entry. Journal of Regulatory Economics 24, 243-259.

46. Henderson, D.J., Millimet, D.L., 2005. Environmental regulation and US statelevel production. Economics Letters 87, 47-53.

47. Huiban, J.P., Musolesi, A., 2012. Augmenting the production function with knowledge capital to test the Porter hypothesis: the case of French food industries. Working Paper ALISS 2012-08.

48. Isik, M., 2004. Environmental regulation and the spatial structure of the US dairy sector. American Journal of Agricultural Economics 86, 949-962.

49. Jug, J., Mirza, D., 2005. Environmental regulations in gravity equations: evidence from Europe. The World Economy 28, 1591-1615.

50. Kahn, M.E., Mansur, E.T., 2013. Do local energy prices and regulation affect the geographic concentration of employment? Journal of Public Economics 105-114.

51. Keller, W., Levinson, A., 2002. Pollution abatement costs and foreign direct investment inflows to U.S. states. Review of Economics and Statistics 691-703.

52. King, A.A., Lenox, M.J., 2001. Does it really pay to be green? An empirical study of firm environmental and financial performance. Journal of Industrial Ecology 5, 105116.

53. Kumar, S., Managi, S., 2010. Sulfur dioxide allowances: Trading and technological progress. Ecological Economics 69, 623-631. 
54. Lanoie, P., Patry, M., Lajeunesse, R., 2008. Environmental regulation and productivity: testing the porter hypothesis. Journal of Productivity Analysis 30, 121-128.

55. Lanoie, P., Laurent-Lucchetti, J., Johnstone, N., Ambec, S., 2011. Environmental policy, innovation and performance: new insights on the Porter hypothesis. Journal of Economics \& Management Strategy 20, 803-842.

56. Lee, M., 2007. The effect of environmental regulations: a restricted cost function for Korean manufacturing industries. Environment and Development Economics 12, 91-104.

57. Li, H. 2012. The Relationship Between Trade and the Environment and Their Impacts on Productivity: Evidence from the US and China. Dissertation.

58. Link, A.N., 1982. Productivity Growth, Environmental Regulations and the Composition of R \& D. The Bell Journal of Economics 548-554.

59. Liu, X. 2008. Industry Environmental Performance, Economic Growth and Environmental Regulation: Evidence from China. 1-94. Dissertation

60. Lundgren, T., Marklund, P.O., 2010. Climate policy and profit efficiency. CERE Working Paper No. 2010:11.

61. Majumdar, S.K., Marcus, A., 2001. Rules versus discretion: the productivity consequences of flexible regulation. Academy of Management Journal 170-179.

62. Managi, S., Kaneko, S., 2004. An Analysis of Economic and Environmental Policies in China: Productivity Approach.

63. Managi, S., Karemera, D., 2005. The effects of environment and technology on agricultural export. International journal of agricultural resources, governance and ecology 4, 45-63.

64. Managi, S., Opaluch, J.J., Jin, D., Grigalunas, T.A., 2005. Environmental regulations and technological change in the offshore oil and gas industry. Land Economics 81, 303-319.

65. Martinez-Zarzoso, I., Vidovic, M., Voicu, A., 2013. Are the Central East European Countries Pollution Havens? Working Paper.

66. Meyer, S.M., 1995. The economic impact of environmental regulation. Journal of Environmental Law \& Practice 3, 4-15.

67. Mulatu, A., Gerlagh, R., Rigby, D., Wossink, A., 2010. Environmental regulation and industry location in Europe. Environmental and Resource Economics 45, 459-479. 
68. Murty, M.N., Kumar, S., 2003. Win-win opportunities and environmental regulation: testing of porter hypothesis for Indian manufacturing industries. Journal of Environmental Management 67, 139-144.

69. Murty, M.N., Kumar, S., Paul, M., 2006. Environmental Regulation, Productive Efficiency and cost of Pollution Abatement: A case study of sugar Industry in India. Institute of Economic Growth, Delhi 1-9.

70. Park, D., Seidl, A., Davies, S., Frasier, W.M. Environmental policy influences on livestock stocking and location decisions. Conference Paper, 2000 Annual Meeting, Western Agricultural Economics Association, June 29-July 1, 2000, Vancouver, British Columbia.

71. Peuckert, J., 2014. What shapes the impact of environmental regulation on competitiveness? Evidence from Executive Opinion Surveys. Environmental Innovation and Societal Transitions 77-94.

72. Quiroga, M., Sterner, T., Persson, M., 2009. Have Countries with Lax Environmental Regulations a Comparative Advantage in Polluting Industries? Working Paper in Economics 412.

73. Ramanathan, R., Black, A., Nath, P., Muyldermans, L., 2010. Impact of environmental regulations on innovation and performance in the UK industrial sector. Management Decision 48, 1493-1513.

74. Rassier, D.G., Earnhart, D., 2010a. The effect of clean water regulation on profitability: testing the Porter hypothesis. Land Economics 86, 329-344.

75. Rassier, D.G., Earnhart, D., 2010b. Does the Porter hypothesis explain expected future financial performance? the effect of clean water regulation on chemical manufacturing firms. Environmental and Resource Economics 45, 353-377.

76. Rassier, D.G., Earnhart, D., 2011. Short-Run And Long-Run Implications Of Environmental Regulation On Financial Performance. Contemporary Economic Policy $29,357-373$.

77. Rassier, D.G., Earnhart, D., 2015. Effects of Environmental Regulation on Actual and Expected Profitability. Ecological Economics 112, 129-140.

78. Ratnayake, R., 1998. Do Stringent Environmental Regulations Reduce International Competitiveness? Evidence from an Inter-industry Analysis. International Journal of the Economics of Business 5, 77-96.

79. Renegar, R.L.A. Which green policy? 2007. An analysis of the relationship between state environmental policy and state economic growth. Dissertation. Louisiana State University. 
80. Rennings, K., Ziegler, A., Zwick, T., 2004. The effect of environmental innovations on employment changes: an econometric analysis. Business strategy and the environment $13,374-387$.

81. Rennings, K., Rammer, C., 2011. The impact of regulation-driven environmental innovation on innovation success and firm performance. Industry and Innovation 18, 255283.

82. Rexhauser S., Rammer, C., 2014. Environmental innovations and firmprofitability: Unmasking the Porter hypothesis. Environmental and Resource Economics 145-167.

83. Roediger-Schluga, T., 2003. Some Micro-Evidence on the 'Porter Hypothesis' from Austrian VOC Emission Standards. Growth and Change 34, 359-379.

84. Rubashkina, Y., Galeotti, M, Verdolini, E., 2015. Environmental Regulation and Competitiveness: Empirical Evidence on the Porter Hypothesis from European Manufacturing Sectors. Energy Policy 83, 288-300.

85. Rutqvist, J. 2009. Porter or Pollution Haven? An analysis of the dynamics of competitiveness and environmental regulations. Working paper.

86. Sanchez-Vargas, A.M., 2013. An Empirical Analysis of the Nonlinear Relationship Between Environmental Regulation and Manufacturing Productivity. Journal of Applied Economics 357-372.

87. Shadbegian, R.J., Gray, W.B., 2005. Pollution abatement expenditures and plantlevel productivity: A production function approach. Ecological Economics 54, 196-208.

88. Stam, E., Thompson, N., Herrmann, A., Hekkert, M. 2012. The Environmental Regulation Paradox for Clean Tech Ventures. EIM Business and Policy Research.

89. Telle, K., Larsson, J., 2007. Do environmental regulations hamper productivity growth? How accounting for improvements of plants' environmental performance can change the conclusion. Ecological Economics 61, 438-445.

90. Testa, F., Iraldo, F., Frey, M., 2011. The effect of environmental regulation on firms' competitive performance: The case of the building \& construction sector in some EU regions. Journal of Environmental Management 2136-2144.

91. Tobey, J.A., 1990. The Effects of Domestic Environmental Policies on Patterns of World Trade: An Empirical Test. 191-209. 
92. Triebswetter, U., Hitchens, D., 2005. The impact of environmental regulation on competitiveness in the German manufacturing industry: a comparison with other countries of the European Union. Journal of Cleaner Production 13, 733-745.

93. Valluru, S.R.K., Peterson, E., 1997. The impact of environmental regulations on world grain trade. Agribusiness 13, 261-272.

94. van Beers, C., Van Den Bergh, J.C.J.M., 1997. An Empirical Multi-Country Analysis of the Impact of Environmental Regulations on Foreign Trade Flows. Kyklos 50, 29-46.

95. van Beers, C., Van Den Bergh, J.C.J.M., 2003. Environmental regulation impacts on international trade: aggregate and sectoral analyses with a bilateral trade flow model. International Journal of Global Environmental Issues 14-29.

96. van der Vlist, A.J., Withagen, C., Folmer, H., 2007. Technical efficiency under alternative environmental regulatory regimes: The case of Dutch horticulture. Ecological Economics 63, 165-173.

97. van Leeuwen, G.M.P. 2015. Revisiting the Porter Hypothesis: An Empirical Analysis of Green Innovation for The Netherlands. Working Paper.

98. $\mathrm{Xu}, \mathrm{X} ., 2$ 2000. International trade and environmental regulation: time series evidence and cross section test. Environmental and Resource Economics 17, 233-257.

99. Yang, C.C., Hsiao, C.K., Yu, M.M., 2008. Technical efficiency and impact of environmental regulations in farrow-to-finish swine production in Taiwan. Agricultural Economics 39, 51-61.

100. Yang, C.H., Tseng, Y.H., Chen, C.P., 2012. Environmental regulations, induced R\&D, and productivity: Evidence from Taiwan's manufacturing industries. Resource and energy economics 514-532.

101. Yang, L., 2010. Do environmental regulations influence the competitiveness of pollution-intensive products? Frontiers of Economics in China 5, 276-298.

102. Zarate-Marco, A., Valles-Gimenez, J., 2013. Environmental tax and productivity in a decentralized context: new findings on the Porter hypothesis. European Journal of Law and Economics.

103. Zhao, Y.H., 2011. The Study of Effect of Carbon Tax on the International Competitiveness of Energy-intensive Industries: An Empirical Analysis of OECD 21 Countries, 1992-2008. Energy Procedia 5, 1291-1302. 


\section{Appendix B}

Publication Sources for 103 Porter Hypothesis Papers

\section{Source}

Number

Working Papers

Ecological Economics

Environmental and Resource Economics

Dissertations

Journal of Productivity Analysis

Journal of Public Economics

Book Chapters

Economics Letters

Energy Policy

Journal of Environmental Management 2

Journal of Political Economy 2

Kyklos

Land Economics

Public Administration Review 2

Research Policy 2

Resource and energy economics 2

Review of Economics and Statistics 2

The World Economy 2

Academy of Management Journal 1

Agribusiness 1

Agricultural Economics $\quad 1$

American Journal of Agricultural Economics $\quad 1$

Applied Economics 1

Business strategy and the environment 1

Canadian Journal of Economics 1

Contemporary Economic Policy 1

Energy Procedia 1

Environment and Development Economics $\quad 1$

Environmental Economics and Policy Studies 1

Environmental Innovation and Societal Transitions 1

European Journal of Law and Economics 1

Frontiers of Economics in China 1

Growth and Change 1

Industry and Innovation $\quad 1$

Int'1 Journal of Agricultural Resources, Governance and Ecology 1

International Journal of Development Planning Literature $\quad 1$

International Journal of Global Environmental Issues 1

International Journal of Production Economics 1

International Journal of the Economics of Business 1 
Journal of Applied Economics

Journal of Cleaner Production 1

Journal of Economic studies

Journal of Economics \& Management Strategy

Journal of Environmental Economics and Management 1

Journal of Environmental Law \& Practice 1

Journal of Evolutionary Economics 1

Journal of Industrial Ecology 1

Journal of Management and Governance 1

Journal of Regional Science $\quad 1$

Journal of Regulatory Economics 1

Management Decision 1

Science Technology \&amp; Society 1

The American Economic Review 1

The Bell Journal of Economics 1

The International Trade Journal 1

The Journal of Industrial Economics 1 


\section{Appendix C}

Authors with Multiple Papers in Meta-Analysis

\begin{tabular}{|c|c|c|c|}
\hline Author & $\begin{array}{l}\text { Affiliation at time of } \\
\text { Publications }\end{array}$ & Co-Authors & $\begin{array}{l} \\
\text { Pubs }\end{array}$ \\
\hline $\begin{array}{l}\text { Earnhart, } \\
\text { Dietrich }\end{array}$ & Univ. of Kansas & Rassier, D. & 4 \\
\hline Gray Wayne B. & Clark Univ. & Shadbegian RJ & 4 \\
\hline $\begin{array}{l}\text { Managi, } \\
\text { Shunsuke }\end{array}$ & $\begin{array}{l}\text { Tokyo Univ. of Agriculture \& } \\
\text { Tech. }\end{array}$ & $\begin{array}{l}\text { Opaluch Jj;jin } \\
\text { D;Grigalunas TA; }\end{array}$ & 4 \\
\hline Rassier, Dylan G. & $\begin{array}{l}\text { U.S. Dept. of Commerce; } \\
\text { PriceWaterhouseCoopers }\end{array}$ & Earnhart, D. & 4 \\
\hline $\begin{array}{l}\text { Costantini, } \\
\text { Valeria }\end{array}$ & $\begin{array}{l}\text { Università degli Studi Roma Tre } \\
\text { (Italy) }\end{array}$ & Crespi, F. & 3 \\
\hline Lanoie, Paul & $\begin{array}{l}\text { École des Hautes Études } \\
\text { Commerciales (Canada) }\end{array}$ & $\begin{array}{l}\text { Dufour, C; Patry, M.; } \\
\text { Lajeunesse; Laurent- } \\
\text { Lucchetti, Johsntone, } \\
\text { N; Ambec, S. }\end{array}$ & 3 \\
\hline $\begin{array}{l}\text { Shadbegian, } \\
\text { Ronald }\end{array}$ & $\begin{array}{l}\text { U.S. Bureau of Census; Univ. of } \\
\text { Massachusetts }\end{array}$ & Gray, W. & 3 \\
\hline $\begin{array}{l}\text { Crespi, } \\
\text { Francesco }\end{array}$ & $\begin{array}{l}\text { Università degli Studi Roma Tre } \\
\text { (Italy) }\end{array}$ & Costantini, V. & 2 \\
\hline Ederington Josh & $\begin{array}{l}\text { Univ. of Miami; Univ. of } \\
\text { Kentucky }\end{array}$ & Levinson A;Minier J; & 2 \\
\hline $\begin{array}{l}\text { Greenstone, } \\
\text { Michael }\end{array}$ & Univ. of Chicago; MIT & List, J.; Syverson, C. & 2 \\
\hline Levinson, Arik & Georgetown Univ. & $\begin{array}{l}\text { Keller, W.; Ederington, } \\
\text { Josh; Minier, J. }\end{array}$ & 2 \\
\hline List, John & $\begin{array}{l}\text { Univ. of Chicago, Univ. of } \\
\text { Maryland }\end{array}$ & $\begin{array}{l}\text { Greenstone, M.; } \\
\text { Syverson, C. }\end{array}$ & 2 \\
\hline $\begin{array}{l}\text { Lundgren, } \\
\text { Tommy }\end{array}$ & Umeå University (Sweden) & $\begin{array}{l}\text { Marklund, ; } \\
\text { Brannlund, R. }\end{array}$ & 2 \\
\hline $\begin{array}{l}\text { Marklund, Per- } \\
\text { Olov }\end{array}$ & Umeå University (Sweden) & $\begin{array}{l}\text { Lundgren, P. Broberg, } \\
\text { T; Samakovlis, E. } \\
\text { Hammar, H. }\end{array}$ & 2 \\
\hline Millimet, Daniel & Southern Methodist Univ. & $\begin{array}{l}\text { Fredriksson, P.G.; List, } \\
\text { John; Henderson, D.J. }\end{array}$ & 2 \\
\hline Minier, Jenny & $\begin{array}{l}\text { Univ. of Kentucky; Univ. of } \\
\text { Miami }\end{array}$ & $\begin{array}{l}\text { Ederington, J; } \\
\text { Levinson, A. }\end{array}$ & 2 \\
\hline $\begin{array}{l}\text { Murty M. } \\
\text { Narshima }\end{array}$ & Delhi Univ. (India) & Kumar S; Paul, M. & 2 \\
\hline Patry, Michel & $\begin{array}{l}\text { École des Hautes Études } \\
\text { Commerciales (Canada) }\end{array}$ & $\begin{array}{l}\text { Dufour, C; Lanoie, P; } \\
\text { Lajeunesse, R. }\end{array}$ & 2 \\
\hline $\begin{array}{l}\text { Rammer, } \\
\text { Christian }\end{array}$ & $\begin{array}{l}\text { Centre for European Economic } \\
\text { Research (ZEW), Germany }\end{array}$ & $\begin{array}{l}\text { Rennings, K. } \\
\text { Rexhauser, S. }\end{array}$ & 2 \\
\hline
\end{tabular}




\begin{tabular}{|l|l|l|l|}
\hline Rennings Klaus & $\begin{array}{l}\text { Centre for European Economic } \\
\text { Research (ZEW), Germany }\end{array}$ & $\begin{array}{l}\text { Rammer C; Ziegler, A.; } \\
\text { Zwick, T. }\end{array}$ & 2 \\
\hline van Beers, Cees & $\begin{array}{l}\text { Leiden Univ. (Netherlands); } \\
\text { Delft Univ. (Netherlands) }\end{array}$ & $\begin{array}{l}\text { Van Den Bergh, } \\
\text { Jeroen; }\end{array}$ & 2 \\
\hline $\begin{array}{l}\text { Van Den Bergh, } \\
\text { Jeroen }\end{array}$ & Vrije Univ. (Netherlands) & van Beers, Cees & 2 \\
\hline Ziegler, Andreas & $\begin{array}{l}\text { Centre for European Economic } \\
\text { Research (ZEW), Germany; } \\
\text { Univ. of Kassel (Germany) }\end{array}$ & $\begin{array}{l}\text { Bohringer, C; } \\
\text { Moslener, U., } \\
\text { Oberndorfer, U., } \\
\text { Rennings, K. Zwick, T. }\end{array}$ & 2 \\
\hline
\end{tabular}

